\title{
Mammoth-hunter Camps in the Scandinavian North Sea Sector during the Late Weichselian?
}

\section{O. Grøn}

For citation: Grøn O. Mammoth-hunter Camps in the Scandinavian North Sea Sector during the Late Weichselian? Vestnik of Saint Petersburg University. History, 2019, vol. 64, issue 2, pp. 555-583. https://doi.org/10.21638/11701/spbu02.2019.209

Until recently, the general view of archaeologists was that southern Scandinavia was uninhabited during the last ice age, the Weichselian glaciation. It was thought that humans arriving from south would have met a wall of ice if they tried to penetrate into the area. Recent climate reconstructions and glaciological data, combined with recent faunal finds from the adjacent North Sea sector, promote the idea of a much more moderate and prosperous landscape with large, now submerged, plains accessible. Then this paper argues that large parts of the South Scandinavian North Sea sector were actually inhabitable during most of this glacial period, with extensive ice-free coastal zones even during the Last Glacial Maximum. It is difficult to believe that humans, already well-documented in the adjacent land areas, should not have known to inhabit and exploit such a rich resource zone. In addition to the paleoenvironmental data, ethnoarchaeological evidence is used to document that it was no problem for humans to kill large animals such as mammoths as some researchers have maintained. Furthermore, findings from excavations of mammoth-hunter sites, are used to argue that the large quantities of megafaunal remains fished up from the North Sea in recent years should be seriously considered as representing settlement material associated with mammoth-hunter camps dating from the second half of the Weichsel Glacial Stage. The central question is whether these North Sea faunal remains represent sites similar to the mammoth-hunter camps known from other parts of Europe and from Siberia? If that is the case, the Cultural Heritage management is confronted with a hitherto unrecognised problem.

Keywords: mammoth hunters, mammoth bone remains, Upper Paleolithic, ethoarchaeology, Scandinavia, North Sea, late Weichselian.

Ole Grøn - PhD, research scientist, University of Geosciences and Natural Resource Management, University of Copenhagen, Østervoldgade, 10, DK 1250, Copenhagen K, Denmark; olegron111@gmail.com

Оле Грюн - д-р философии (археология), науч. сотр., Копенгагенский университет, Дания, DK 1250, Копенгаген К, Остервольдгаде, 10; olegron111@gmail.com

Anders Fischer, Vladimir Pitulko, Jane Richter, Pål Nymoen, Jan Michael Burdukievicz, Luc Amkreutz, Marcel J.L.T.Niekus, Marine Dunsmore and Stefan Wenzel are all thanked for comments and suggestions relating to various versions of this manuscript. Nic Flemming is thanked for adding his own observations to the review of published information on the collection of mammoth faunal remains from the North Sea

Автор выражает благодарность за комментарии и предложения, касающиеся различных версий этой рукописи Андерсу Фишеру, Владимиру Питулько, Джейн Рихтер, Полу Нимоену, Яну Майклу Бурдукиевич, Люку Амкройц, Марселю Ж. Л. Ниекус, Марин Дунсморе и Стефану Вензелю. Отдельная благодарность Нику Флеммингу за предоставление своих наблюдений в обзор опубликованной информации о сборе останков мамонтовой фауны из Северного моря.

(C) Санкт-Петербургский государственный университет, 2019 


\section{Лагеря охотников на мамонтов в Скандинавском секторе Северного моря во время последнего вислинского оледенения?}

О. Грюн

Для цитирования: Grøn O. Mammoth-hunter Camps in the Scandinavian North Sea Sector during the Late Weichselian? // Вестник Санкт-Петербургского университета. История. 2019. Т. 64. Вып. 2. С. 555-583. https://doi.org/10.21638/11701/spbu02.2019.209

До недавних пор в археологическом сообществе было распространено мнение о том, что Южная Скандинавия в последнюю (вислинскую) ледниковую эпоху оставалась незаселенной человеком. Так, считалось, что двигавшиеся с юга группы людей при попытке проникнуть на эту территорию столкнулись бы с ледяной стеной. Последние реконструкции климата в совокупности с гляциологическими данными и новыми фаунистическими находками в прилегающем секторе Северного моря дают основания предполагать более умеренный и благоприятный ландшафт с обширными равнинными участками, ныне затопленными. Таким образом, показано, что значительные области южно-скандинавского сектора Северного моря были обитаемы на протяжении значительной части ледниковой эпохи, в течение которой даже во время последнего ледникового максимума существовали обширные безледные прибрежные зоны. С трудом можно допустить, что люди, присутствие которых на прилегающих сухопутных территориях несомненно, не могли бы заселить и использовать столь богатую ресурсами зону. В дополнение к палеогеографическим данным для доказательства данного тезиса в работе использованы этноархеологические свидетельства, показывающие, что охота даже на таких крупных животных, как мамонты, не представляла собой проблемы для древнего человека. Данные, полученные в результате раскопок стоянок охотников на мамонтов, привлечены для обоснования того, что массовые находки костных остатков мегафауны, в большом количестве собранные в последние годы в результате тралового лова рыбы в Северном море, могут рассматриваться в качестве материалов поселенческих структур, относящихся ко второй половине поздней стадии вислинского оледенения. Главный вопрос состоит в том, являются ли фаунистические остатки, поднятые в Северном море, остатками материалов со стоянок, подобных лагерям охотников на мамонтов, известных в других частях Европы и в Сибири. Если это так, то возникает ранее неизвестная проблема администрирования объектов культурного наследия.

Ключевые слова: охотники на мамонтов, костные остатки мамонтов, верхний палеолит, этноархеология, Скандинавия, Северное море, поздняя стадия вислинского оледенения.

\section{Introduction - the setting (1)}

Until recently, the Scandinavian North Sea sector was not seen as a relevant area for maritime archaeological investigations of Stone Age remains. Despite the recovery of tree stumps and a range of Mesolithic artefacts ${ }^{1}$, erosion and redeposition of sediment in this

${ }^{1}$ Fischer A. Submerged Stone Age - Danish examples and North Sea potential // Submarine prehistoric archaeology of the North Sea. Research priorities and collaboration with industry. CBA Research Report 141. English Heritage/Council for British Archaeology. 2004. P.23-36; Koijmans L. Mesolithic Bone and Antler Implements from the North Sea and from the Netherlands // Berichten van de Rijksdienst voor het Oudheidkundig Bodemonderzoek. Jaargang 20-21. 1971. P.27-73; Reid C. Submerged Forest. Cambridge, 1913. 
dynamic environment were thought to have effectively erased any cultural deposits, leaving only heavily abraded artefacts as remnants of former cultural contexts ${ }^{2}$.

An increasing general focus on submerged Stone Age archaeology, inspired to some degree by significant industrial development of off-shore technology, has recently prompted a systematic appraisal of the potential for locating and investigating submerged Stone Age sites from glacial periods when the sea level was significantly lower than it is today. It is a well-established fact that significant parts of the continental shelf were inhabited during various Stone Age epochs. As far as the English Channel is concerned, for instance, a settlement on land now partly located below present sea level has recently been shown to date back almost a million years in Happisburgh in eastern England ${ }^{3}$.

\section{1.a. The environmental setting}

A central problem relating to the understanding of Stone Age settlement during prehistoric glacial periods is that a rather primitive form of modelling has generally been applied to environmental-cultural interactions in archaeological studies. The edges of prehistoric ice sheets have been perceived as simple walls of ice that blocked human access to 'glaciated' areas covering northern land surfaces ${ }^{4}$. Very little attention has been paid to the importance of land/sea interfaces, including the quite common broad ice-free corridors running between the 'outer coast' and the 'inland ice margin', as recognised in modern glaciology 5 .

${ }^{2}$ Coles B. Doggerland: a Speculative Survey // Proceedings of the Prehistoric Society. Vol.64. 1998. P. 45-81.

3 Ashton N., Lewis S. G., De Groote I., Duffy S. M., Bates M., Bates R., Hoare P., Lewis M., Parfitt S. A., Peglar S., Williams C., Stringer C. Hominin Footprints from Early Pleistocene Deposits at Happisburgh, UK // PLOS ONE. February 2014. Vol. 9, iss. 2, 13 p.; Bailey G., Sakellariou D. et al. SPLASHCOS: Submerged Prehistoric Archaeology and Landscapes of the Continental Shelf // Antiquity. Vol. 086, iss. 334. December 2012; Bicket A. Submerged Prehistory: Marine ALSF Research in Context. Marine ALSF Science Monograph Series No. 5. (Ed. J. Gardiner). MEPF 10/P150. 2011.; Dix J., Quinn R., Westley K. Re-assessment of the archaeological potential of continental shelves // English Heritage ALSF project No. 3362. University of Southampton, 2008; Flemming N. Research Infrastructure for Systematic Study of the Prehistoric Archaeology of the European Submerged Continental Shelf // Submerged Prehistory. Oxford, 2011. P. 287-297; Grøn O., Froberg Mortensen L. Stone Age in the Danish North Sea Sector // Maritime Archaeology Newsletter from Denmark. No.26, Summer 2011. P.3-8; Parfitt S. A., Ashton N. M., Lewis S. G., Abel R. L., Russell Coope G., Field M.H., Gale R., Hoare P.G., Larkin N.R., Lewis M.D., Karloukovski V., Maher B.A., Peglar S.M., Preece R. C., Whittaker J. E., Stringer C. B. Early Pleistocene human occupation at the edge of the boreal zone in northwest Europe // Nature. Vol.466, iss. 7303, 8 Jul. 2010. P. 229-233; Peeters H. North Sea Prehistory Research and Management Framework (NSPRMF). Amersfoort, 2009; Arch-Manche: Archaeology, Art and Coastal Heritage - tools to support management and climate change planning across the Channel Regional Sea: Technical Report // Arch-Manche Technical Report / Eds J. Satchel, L. Tidbury. September. 2014. P. 40; Tizzard L., Bicket A., De Loecker D. Seabed Prehistory. Investigating the Palaeogeography and Early Middle Palaeolithic Archaeology in the Southern North Sea. Wessex Archaeology Report 35. 2015.

${ }^{4}$ Bordes F. The Old Stone Age. Toronto, 1972. P.9-10, 213; Coles J. M., Higgs E. S. The Archaeology of Early Man. London, 1975. P. 18, 419; Honoré P. Das Buch der Altsteinzeit - oder der Streit um die Vorfahren. Wien, 1967. P. 101, 399, 406, 430.

${ }^{5}$ Barron E., van Andel T.H., Pollard D. Glacial Environments II: Reconstructing the Climate of Europe in the Last Glaciation // Neanderthals and modern humans in the European landscape during the last glaciation: archaeological results of the Stage 3 Project. University of Cambridge, 2003. P.57-78; Kelly M. A., Long A. J. The dimensions of the Greenland Ice Sheet since the Last Glacial Maximum // PAGES News. Vol. 17, no. 2, June 2009. P. 60-61; Lambeck K., Purcell A., Zhao J., Svensson N.-O. The Scandinavian Ice Sheet: from MIS 4 to the end of the Last Glacial Maximum // BOREAS. Vol.39, no. 2. 2010. P.410-435; 


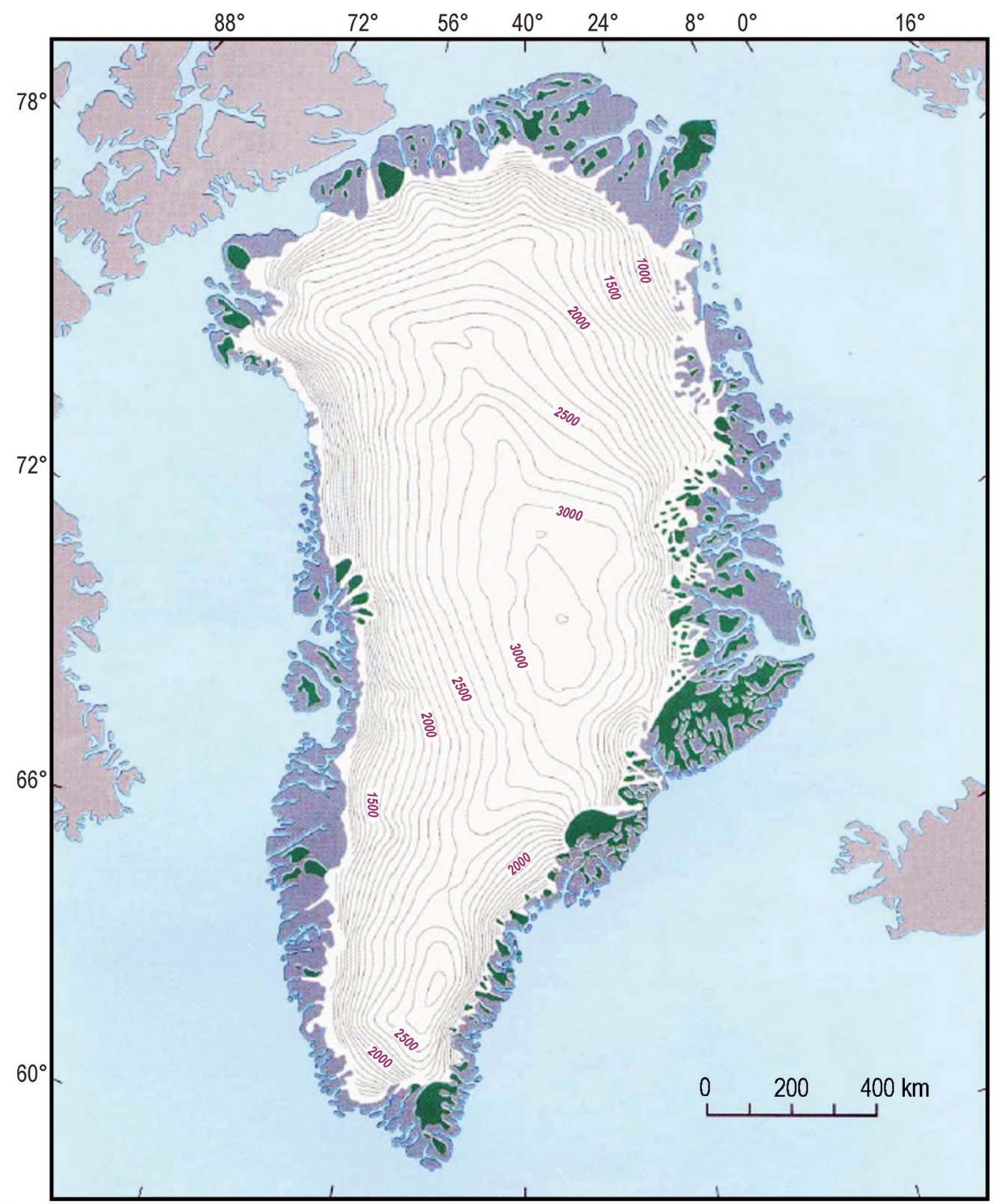

Fig. 1. The permanent ice sheet on Greenland consists of a number of glaciers flowing from the interior out towards the coast. In some areas these glaciers reach fjords where they break up to form icebergs. In other areas the ice melts or evaporates before it reaches the coast. The outer coast does not have permanent ice cover [Weidick, 1995]

Mackintosh A., Colledge N., Domack E., Dunbar R., Leventer A., White D., Pollard D., DeConto R., Fink D., Zwartz D., Gore D., Lavoie C. Retreat of the Antarctic ice sheet during the last glacial termination // Nature Geoscience. Vol. 4. 2011, March. P. 195-202; Påsse T., Andersson L. Shore-level displacement in Fennoscandia calculated from empirical data // GFF. Vol.127 (2005). P.253-268; Weidick A., Bennike O. Quaternary glaciation history and glaciology of Jakobshavn Isbræ and the Disko Bugt region, West Greenland: a review. Copenhagen, 2007. P. 12, 48-49. 
There are numerous past and present examples of glaciated areas with ice-free outer coasts, such as modern Greenland (Fig. 1) and the Antarctic during the Last Glacial Maximum, as well as several other similar prehistoric situations ${ }^{6}$. In other cases, the ice sheet extends or extended beyond the coastline and into the sea as shelf ice ${ }^{7}$.

A complex set of factors controls the configuration of glacial coasts: precipitation, melting of and evaporation from the ice sheet, altitude of the snow line, rate of growth of the ice sheet, sea temperature, presence/absence of permanent sea ice and so on ${ }^{8}$. Permanent sea ice will, due to its insulating effect, reduce the impact of the relatively warm seawater (warmer than $\mathrm{c} .-1.8^{\circ} \mathrm{C}$ ) on a land-based ice sheet and deflect the sun's rays more efficiently than open water, thereby reducing the sun's heating effect on the sea ${ }^{9}$. The potential for formation of permanent sea ice will depend on a series of factors, such as the depth and bathymetry of the seabed, currents, wind conditions, etc. ${ }^{10}$ Recent reconstructions of the Weichselian landscape show extensive ice-free coastal and inland zones for the Scandinavian North Sea margin which, in the southernmost zone, persist throughout the entire glaciation. The Norwegian coast may have been ice-covered through most of the later Weichselian, but its ice/land/sea configuration during this period is difficult to reconstruct in detail ${ }^{11}$.

${ }^{6}$ Long A. J., Roberts D. H., Wright M. R. Isolation basin stratigraphy and Holocene relative sea-level change on Arvepinsen Ejland, Disko Bugt, West Greenland // Journal of Quaternary Science. Vol. 14(4). 1999. P.323-345; Mackintosh A., Colledge N., Domack E., Dunbar R., Leventer A., White D., Pollard D., DeConto R., Fink D., Zwartz D., Gore D., Lavoie C. Retreat of the Antarctic ice sheet during the last glacial termination // Nature Geoscience. Vol.4, March 2011. P. 195-202; Weidick A., Bennike O. Quaternary glaciation history and glaciology of Jakobshavn Isbræ and the Disko Bugt region, West Greenland: a review. Copenhagen, 2007. P. 12.

7 Lemke P., Ren J., Alley R. B., Allison I., Carrasco J., Flato G., Fujii Y., Kaser G., Mote P., Thomas R. H., Zhang T. Observations: Changes in Snow, Ice and Frozen Ground // Climate Change 2007: The Physical Science Basis. Contribution of Working Group I to the Fourth Assessment Report of the Intergovernmental Panel on Climate Change. 2007. P. 341; Sejrup H.P., Larsen E., Haflidason H., Berstad I. M., Hjelstuen B. O., Jonsdottir H., King E.L., Landvik J., Longva O., Nygård A., Ottesen D., Raunholm S., Rise L., Stalsberg K. Configuration, history and impact of the Norwegian Channel Ice Stream // Boreas. 2003. Vol. 32. P. 18-36.

8 Dansgaard W., White J.W.C., Johnsen S. J. The abrupt termination of the Younger Dryas climate event // Nature. Vol.339. 15 June. 1989. P.532-534; Lemke P., Ren J., Alley R. B., Allison I., Carrasco J., Flato G., Fujii Y., Kaser G., Mote P., Thomas R. H., Zhang T. Observations: Changes in Snow, Ice and Frozen Ground. P.341; Weidick A., Bennike O. Quaternary glaciation history and glaciology of Jakobshavn Isbræ and the Disko Bugt region, West Greenland: a review. Copenhagen, 2007. P.28-64.

9 Armand L.K., Leventer A. Palaeo Sea Ice Distribution - Reconstruction and Palaeoclimatic Significance // Sea Ice. An Introduction to its Physics, Chemistry, Biology and Geology. Oxford, 2003. P. 333-372; Gildor H., Tziperman E. Sea ice as the glacial cycles' climate switch: Role of seasonal and orbiting forcing // Paleoceanography. Vol. 15(6). 2000. P. 605-615; Golden K. M. Climate Change and the Mathematics of Transport in Sea Ice // Notices of the American Mathematical Society. Vol.56(5). 2009. P. 562-584

10 Leventer A. Particulate Flux from Sea Ice in Polar Waters // Sea Ice. An Introduction to its Physics, Chemistry, Biology and Geology. Oxford, 2003. P. 303-332; Morison J., Kwok R., Peralta-Ferritz C., Alkire M., Rigor I., Steele M. Changing Arctic Ocean freshwater pathways // Nature. Vol. 481.5 January. 2012. P. 66-70; Nghiem S. V., Clemente-Colón P., Rigor I. G., Hall D. K., Neumann G. Seafloor control on sea ice // Deep-Sea Research II. Vol.77-80. 2012. P. 52-61.

11 Barron E., van Andel T. H., Pollard D. Glacial Environments II: Reconstructing the Climate of Europe in the Last Glaciation. (Eds.) Tjeerd H.van Andel and William Davies // Neanderthals and modern humans in the European landscape during the last glaciation: archaeological results of the Stage 3 Project. McDonald Institute for Archaeological Research, University of Cambridge, 2003. P.57-78; Lambeck K., Purcell A., Zhao J., Svensson N.-O. The Scandinavian Ice Sheet: from MIS 4 to the end of the Last Glacial Maximum // BOREAS. Vol.39, no. 2. 2010. P. 410-435; Mangerud J. Ice sheet limits in Norway and on the Norwegian continental shelf // Quaternary Glaciations - Extent and Chronology. Vol. 1. 2004. P.271-294; 
In addition to abandoning simplistic ideas about the principles of interaction between human cultures and prehistoric glacial landscapes, we must also accept the existence of greater climatic and environmental complexity and dynamics during these glacial periods. The Greenland ice cores (DYE-3, GRIP, GISP2, NGRIP and NEEM) have revolutionised our ideas of climate dynamics ${ }^{12}$. Given the early date demonstrated for Happisburgh ${ }^{13}$, we should be aware of the possible existence in northern Europe of submerged sites during the glacial periods, with their low sea levels and relatively high coastal temperatures, as far back as a million years ago.

A further important argument for the existence of deep coastal Stone Age sites is that, apart from tropical rainforests, shallow marine coasts represent the most productive biotope in existence ${ }^{14}$, and they are therefore especially attractive to humans.

\section{1.b. Cultural factors}

Based on studies of the historical territorial development of Australian hunter-gatherer groups, Peter Sutton suggests that the more successful of these groups managed, over time, to extend and move their territories out to the highly productive seashore ${ }^{15}$. Information about very successful coastal hunter-gatherer groups, such as the Northwest Coast Indians, the coastal Nivkh/Gilyak of the Amur River estuary and the Ainu of Sakhalin and Hokkaido, also seems to support the general idea that highly productive marine coasts ${ }^{16}$ hold a particular attraction for humans and represent a special potential for human cultural development ${ }^{17}$. A growing understanding of the importance of coastal resources in the Palaeolithic, including the Late Palaeolithic of northern Europe, is reflected in the more recent literature ${ }^{18}$.

Påsse T., Andersson L. Shore-level displacement in Fennoscandia calculated from empirical data // GFF. Vol. 127. 2005. P.253-268.

12 Austin W. E. N., Hibbert F. D., Rasmussen S. O., Peters C., Abbot P. M., Bryant C. L. The synchronization of palaeoclimatic events in the North Atlantic region during Greenland Stadial 3 (ca 27.5 to $23.3 \mathrm{kyr}$ b2k) // Quaternary Science Reviews. Vol. 36. 2012. P. 154-164.

13 Ashton N., Lewis S. G., De Groote I., Duffy S. M., Bates M., Bates R., Hoare P., Lewis M., Parfitt S. A., Peglar S., Williams C., Stringer C. Hominin Footprints from Early Pleistocene Deposits at Happisburgh, UK // PLOS ONE. February 2014. Vol.9, iss.2. 13 p.

14 Odum E. P., Barrett G. W. Fundamentals of Ecology. Belmont, 2005.

15 Sutton P. The Pulsating Hearth: Large Scale Cultural and Demographic Processes in Aboriginal Australia // Hunter-Gatherer Demography. Past and Present. University of Sydney, 1990. P.71-80.

16 Odum E. P., Barrett G. W. Fundamentals of Ecology. Belmont, 2005.

17 Black L. The Nivkh (Gilyak) of Sakhalin and the Lower Amur // Arctic Anthropology. Vol. 10(1). 1973. P. 1-110; Ohnuki-Tierney E. The Ainu of the Northwest Coast of Southern Sakhalin. New York, 1974; Shternberg L.I. The Socal Organisation of the Gilyak // Anthropological Papers of The American Museum of Natural History. No. 82, 1999; Northwest Coast / ed. by W. Suttles. Washington, 1990; Watanabe H. The Ainu Ecosystem. Environment and Group Structure. Seattle, 1973.

18 Bjerck H. B. Tidligmesolittsk tid (TM) og Fosnatradisjon 9500-8000 BC. // Ormen Lange Nyhamnia. NTNU Vitenskapsmuseets arkeologiske undersøkelser. Trondheim, 2008. P. 552-570; Bjerck H. B. Colonising seascapes: comparative perspectives on the development of maritime relations in the Pleistocene/Holocene transition in north-west Europe // Mesolithic Horizons. Oxford, 2009. P. 16-23; Bradley B., Stanford $D$. The North Atlantic ice-edge corridor: a possible Palaeolithic route to the New World // World Archaeology. Vol.36(4). 2004. P. 459-478; Cortés-Sánchez M., Morales-Muñiz A., Simón-Vallejo M.D., Lozano-Francisco M.C., Vera-Peláez J.L., Finlayson C., Rodriguez-Vidal J., Delgado-Huertas A., Jiménez-Espejo F. J., Martínez-Ruiz F., Martínez-Aguirre M. A., Pascual-Granged A. J., Bergadà-Zapata M. M., Gibaja-Bao J.F., Riquelme-Cantal J. A., López-Sáez J. A., Rodrigo-Gámez M., Sakai S., Sugisaki S., Finlayson G., Fa D. A., Bicho N. Earliest Known Use of Marine Resources by Neanderthals // PLoS one. Vol. 6(9): e24026. 2011. Available: 
Territorial manoeuvring over time at clan level, or direct migration, either locally or over greater distances, are both well-known phenomena in hunter-gatherer societies ${ }^{19}$. This introduces the interesting possibility that deeper submerged coastlines may have been densely populated by cultural groups that differed markedly from those we can observe in today's terrestrial situations.

The author has had the opportunity to study the Siberian Evenk and has recorded a rather high level of curiosity-driven long-distance travel by them. This concurs with Parry's observations of the Inuit living in the Melville Peninsula area ${ }^{20}$. Long-distance pre-contact trading expeditions to areas more than a thousand kilometres from their homes appear to have been a well-known phenomenon among the Indians of the Canadian Plains as well as those of the North American Southwest. Travel and related exchange activities must be seen as something in which hunter-gatherers liked to engage ${ }^{21}$.

https://journals.plos.org/plosone/article?id=10.1371/journal.pone.0024026 (accessed: 04.02.2019); Fischer A., Mortensen M. F., Henriksen P. S., Mathiassen D. R., Olsen J. Dating the Trollesgave site and the Bromme culture - chronological fix-points for the Lateglacial settlement of Southern Scandinavia // Journal of Archaeological Science. 2013. Vol. 40 P. 1-12; E18 Brunlanesprosjektet. Arkeologiske undersøkelser i Larvik kommune, Vestfold fylke. Årsrapport 2007. Oslo, 2008. P. 42-51, 59-61; E18 Brunlanesprosjektet. Arkeologiske undersøkelser i Larvik og Porsgrunn kommuner, Vestfold og Telemark fylker. Årsrapport 2008 / ed. by L. Jaksland. Oslo, 2009. P.19-27, 30-31; Parfitt S. A., Barendregt R. W., Breds M., Collins M.J., Coope G.R., Durbridge P., Field M.H., Lee J.R., Lister A.M., Mutch R., Penkman K.E.H., Preece R. C., Rose J., Stringer C. B., Symmons R., Whittaker J.E., Wymer J.J., Stuart A. J. The earliest record of human activity in northern Europe // Nature. 2005. Vol.438, no. 7070, 15 December. P. 1008-1012; Parfitt S. A., Ashton N. M., Lewis S. G., Abel R. L., Russell Coope G., Field M.H., Gale R., Hoare P. G., Larkin N. R., Lewis M. D., Karloukovski V., Maher B. A., Peglar S. M., Preece R. C., Whittaker J. E., Stringer C. B. Early Pleistocene human occupation at the edge of the boreal zone in northwest Europe // Nature. 2010. Vol.466, no. 7303, 8 July. P. 229233; Ramos J., Domíguez-Bella S., Cantillo J.J., Soriguer M., Pérez M., Hernando J., Vijande E., Zabala C., Clemente I., Bernal D. Marine resources exploitation by Palaeolithic hunter-fisher-gatherers and Neolithic tribal societies in the historical region of the Strait of Gibraltar // Quaternary International. 2011. Vol.239. P. 104-113; Richards M. P., Jacobi R., Cook J., Pettitt P. B., Stringer C. B. Isotope evidence for the intensive use of marine foods by Late Upper Palaeolithic humans // Journal of Human Evolution. 2005. Vol. 49. P. 390-394; Shackleton J. C., van Andel T. Prehistoric Shore Environments, Shellfish Availability, and Shellfish Gathering at Frantchi, Greece // Geoarchaeology. 1986. Vol.1, no.2. P.127-143; Wikell R., Molin F., Pettersson M. The archipelago of Eastern Middle Sweden - Mesolithic settlement in comparison with C14 and shoreline dating // Chronology and Evolution within the Mesolithic of North-West Europe. 2009. P. 417-434.

19 Alden Smith E., Hill K., Marlowe F. W., Nolin D., Wiessner P., Gurven M., Bowles S., Mulder M. B., Hertz T., Bell A. Wealth Transmission and Inequality among Hunter-Gatherers // Current Anthropology. 2010. Vol. 51 (1), February. P. 19-34; Grøn O., Turov M., Klokkernes T. Settling in the landscape - settling the land: Ideological aspects of territoriality in a Siberian hunter-gatherer society // Archaeology of Settlements and Landscape in the North Umeå University. 2008. P. 57-80; Layton R. Political and Territorial Structures Among Hunter-Gatherers // Man. New Series. 1986. Vol.21(1), March. P. 18-33; Pettipas L. Aboriginal Migrations. A History of Movements in Southern Manitoba. Manitoba, 1996; Raghavan M. et al. Upper Palaeolithic Siberian genome reveals dual ancestry of Native Americans // Nature. 2014. Vol.505, no. 7481, 2 January. P. 87-94; Reich D., Patterson N., Campbell D., Tandon A., Mazieres S. et al. Reconstructing Native American population history // Nature. 2012. Vol.488, no. 7411, 16 August. P. 370-376.

20 Parry W.E. Journal of a Second Voyage for the Discovery of a North-West Passage from the Atlantic to the Pacific; Performed in the Years 1821-22-23 in his Majesty's ships Fury and Hecla, under the Orders of Captain William Edward Parry, R. N., F. R.S., and Commander of the Expedition. London, 1824. P.175, 185, 196-199, 252, 296, 303-305, 512-513.

${ }^{21}$ Brown J.S.H. History of the Canadian Plains Until 1870 // Handbook of North American Indians. Vol. 13 - Plains. Washington, 2001. P.300-312; Clark J. G.D. Prehistoric Europe. The Economic Basis. London, 1952. P. 241-256; Fitzgerald R. T., Jones T.L., Schroth A. Ancient long-distance trade in Western North America: new AMS radiocarbon dates from Southern California // Journal of Archaeological Science. Vol. 32. 2005. P. 423-434; Grindon A. J., Davison A. Irish Cepaea nemoralis Land Snails Have a Cryptic Franco-Iberian Origin That Is Most Easily Explained by the Movements of Mesolithic Humans // PLoS ONE 
Whereas the southernmost parts of the Scandinavian North Sea coastal areas and their hinterlands were apparently without ice cover throughout the entire Weichselian glaciation, and the Danish North Sea zone was only partly glaciated during the relatively short Late Glacial Maximum, it is possible that larger parts of the Norwegian North Sea coast were glaciated even though there were most probably significant ice-free refugia ${ }^{22}$. This does not imply, however, that it would have been a problem for humans to move around and subsist here. With an ice sheet extending all the way to the sea, there should be a good basis for solid sea ice in winter, which is traditionally the travelling season in northern coastal areas. 'The Sea Ice is Our Highway' is for instance the title of a contribution to the Arctic Marine Shipping Assessment from the Inuit Circumpolar Council of Canada (2008). The Inuit have demonstrated that a winter economy based on fishing and hunting through and on sea ice can be quite an attractive option ${ }^{23}$.

On the other hand, if there was a generally unglaciated land/sea interface, transportation along the North Sea Coast without boats would also be an obvious possibility. The presence or absence of people along the Scandinavian North Sea coast seems therefore mainly to have been a question of the nature of the available resources.

\section{Evidence for a mammoth fauna at the ice/land/sea interface in the Scandinavian North Sea sector during the Weichselian glaciation}

The huge quantities of faunal remains trawled up by Dutch fishermen from the North Sea, including the Danish North Sea sector, show that an actual mammoth fauna existed here for extensive periods during the second half of the Weichselian glaciation ${ }^{24}$. In turn,

8(6): e65792. 2013. Available: https://journals.plos.org/plosone/article?id=10.1371/journal.pone.0065792 (accessed: 04.02.2019); Klassen L. Jade und Kupfer. Untersuchungen zum Neolithisierungsprozess im westlichen Ostseeraum unter besonderer Berücksichtigung der Kulturentwicklung Europas 5500-3500 BC. Aarhus, 2009. P. 24-148; Ray A. J. Some Thoughts about the Reasons for Spatial Dynamism in the Early Fur Trade. 1580-1800 // Three Hundred Prairie Years: Henry Kelsey's "Inland Country of Good Report”. University of Regina, 1993. P. 114, 121; Reimer R. Reassessing the role of Mount Edziza obsidian in northwestern North America // Journal of Archaeological Science: Reports 2 (2015). P.418-426; Swagerty W.R. Indian Trade in the Trans-Mississippi West to 1870 // Handbook of North American Indians Vol.4 - History of Indian - White Relations. Washington, 1988. P.351-374; Sulgosłowska Z. Mesolithic mobility and contacts on areas of the Baltic Sea watershed, the Sudety, and Carpathian Mountains // Journal of Anthropological Archaeology. 2006. Vol.25. P. 193-203.

${ }^{22}$ Barron E., van Andel T.H., Pollard D. Glacial Environments II: Reconstructing the Climate of Europe in the Last Glaciation // Neanderthals and modern humans in the European landscape during the last glaciation: archaeological results of the Stage 3 Project. Cambridge, 2003. P.57-78; Lambeck K., Purcell A., Zhao J., Svensson N.-O. The Scandinavian Ice Sheet: from MIS 4 to the end of the Last Glacial Maximum // BOREAS. 2010. Vol. 39, no. 2. P. 410-435; Mangerud J. Ice sheet limits in Norway and on the Norwegian continental shelf // Quaternary Glaciations - Extent and Chronology. Vol. 1 Europe, Elsevier. Amsterdam, 2004. P. 271-294; Parducci L., Jørgensen T., Tollefsrud M. M., Elverland E., Alm T., Fontana S. L., Bennett K.D., Haile J. Matetovici I., Suyama Y., Edwards M.E. Andersen K., Rasmussen M., Boessenkool S., Coissac E., Brochmann C., Taberlet P., Houmark-Nielsen M., Krog Larsen N., Orlando L., Gilbert T.P., Kjor K. H., Greve Alsos I., Willerslev E. Glacial Survival of Boreal Trees in Northern Scandinavia // Science. 2012. Vol.335, 2 March. 2014. P. 1083-1087; Påsse T., Andersson L. Shore-level displacement in Fennoscandia calculated from empirical data // GFF. 2005. Vol. 127. P.253-268.

${ }^{23}$ Birket-Smith K. The Chugach Eskimo // Nationalmuseets Skrifter, Ecnografisk Række, VI, Copenhagen, 1953.

${ }^{24}$ Glimmerveen J., Mol D., Post K., Reumer J. W. F., van der Plicht H., de Vos J., van Reenen G., Pals J.P. Submarine prehistoric archaeology of the North Sea. Research priorities and collaboration with industry // CBA Research Report 141, English Heritage/Council for British Archaeology. 2004. P. 43-52. 


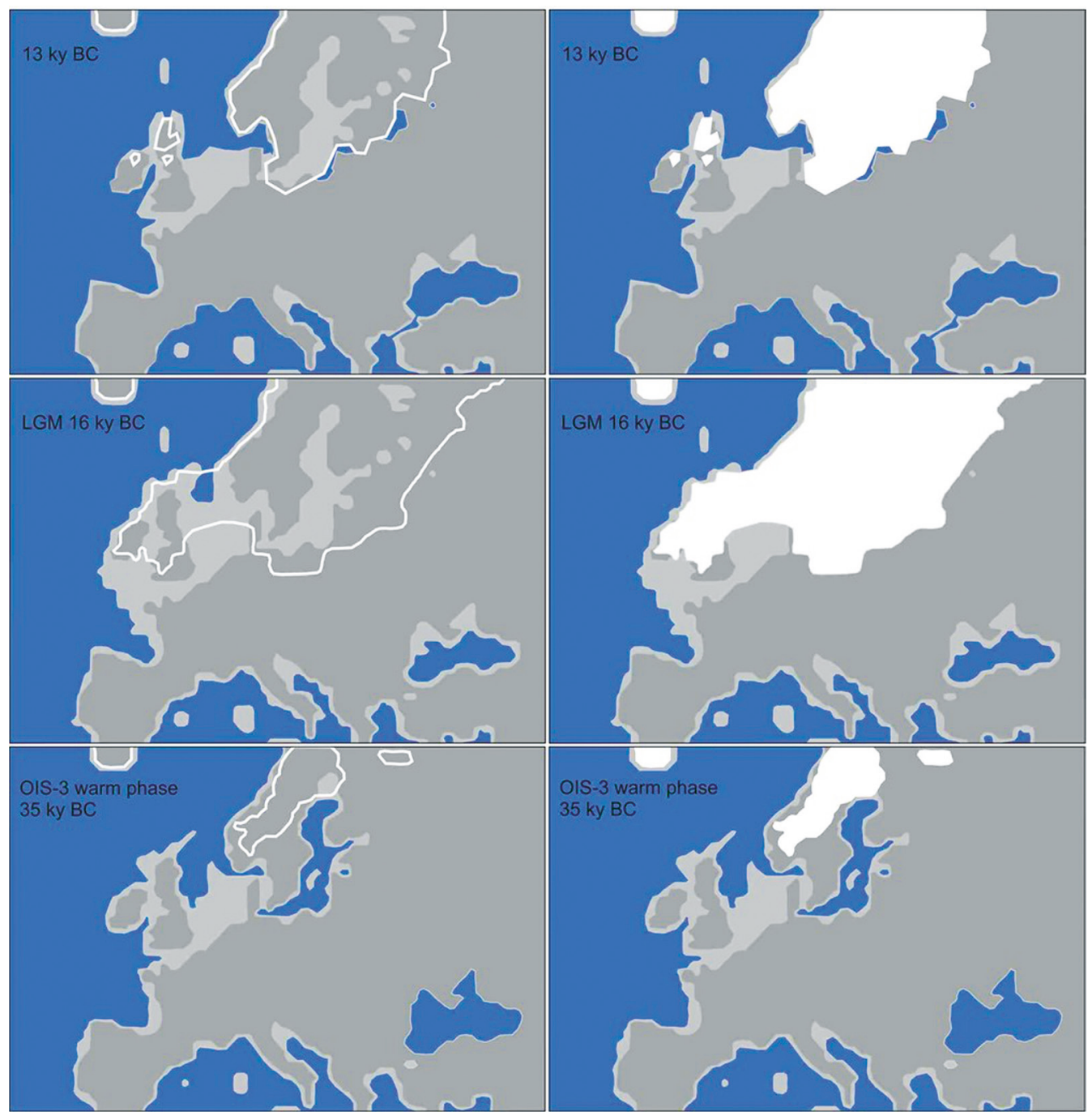

Fig. 2. Sketch maps showing the distribution of land, sea and ice during three phases of the last glaciation (the Weichselian $-117 \mathrm{ky}-11.6 \mathrm{ky} \mathrm{BP}$ ). Right: Ice sheets shown as white areas. Left: Ice sheets shown as transparent areas with white outlines to give a better impression of the present-day areas they covered. Water: blue; land today: dark grey; additional land during the different phases: light grey. Top: 15 ky BP. Middle: Last Glacial Maximum - LGM - 18 ky BP. Bottom: OIS-3 warm phase 37 ky BP. Based on [Barron et al., 2003; Clark et al., 2012; Sejrup et al., 2000; Sejrup et al., 2003; and Svendsen et al., 2004]

this demonstrates the existence here of extensive and highly productive ice-free coastal landscapes. Regardless of the debate about the type of vegetation upon which the mammoth fauna depended, and also helped to maintain, there is no doubt that the existence of extensive open landscapes was a precondition for their presence in this area ${ }^{25}$.

${ }^{25}$ Kozhevnikov J.P., Ukraintseva V. V. Pleistocene tundra-steppe: arguments pro and con // Mammoths and the Mammoth Fauna: Studies of an Extinct Ecosystem. Proceedings of the First International Mammoth 
Mammoth remains have been recovered from the Dutch and British North Sea sectors for the past 150 years and are heavily represented in Dutch natural history muse$u^{u m s} s^{26}$ (Fig. 3). Over a period of about 40 years, enormous quantities of palaeontological remains, including bones of mammoth, deer, woolly rhinoceros, wolf, bear, musk-ox, sabre-toothed tiger and other species, were recovered from the sea by Dutch fishermen using beam trawls. This is a type of trawl that, until the technology was recently improved, scraped through the upper $30-40 \mathrm{~cm}$ of the seabed with a heavy metal chain. The consumers of this by-catch were palaeontological collectors around the world. The material was sorted into categories for sale, which is legally permitted, as the material was allegedly found outside the territorial limit of 24 nautical miles ${ }^{27}$. There was a requirement to report bone artefacts to the archaeological authorities, and this rule was complied with. A qualified estimate is that, during this 40-year-period, about 10-20 tonnes of diverse palaeontological remains were landed each year by trawlers at the various ports.

The items acquired by palaeontological collectors have, in some cases, been analysed and presented in scientific publication ${ }^{28}$, while bones that were sold commercially have probably not been recorded or published. Most of the faunal remains have been found across a wide area straddling the Dutch-UK maritime boundary in the central-southern part of the North Sea, although some have been recovered further north in the UK, German and Danish sectors.

Radiocarbon dates have been published for several items, with an apparent focus on material from the Brown Bank. The time interval indicated by the 13 dates for mammoth, two for musk-ox and one each for giant deer and hyena, is 45-34 ky BP. The nine dates for reindeer span the interval from $45 \mathrm{ky}-30 \mathrm{ky} \mathrm{BP}^{29}$. The mammoth fauna recovered from the Eurogeul shipping lane and the Yangtze harbour in the Rotterdam area, and especially its later part in the Dutch Yangtze Harbour study, has also been dated to the Weichselian glaciation ${ }^{30}$.

Conference St. Petersburg, Russia, October 16-21, 1995. DEINSEA 6. 1999. P.199-210; Putshkov P.V. The impact of mammoths on their biome: clash of two paradigms // Advances in Mammoth Research. Proceedings of the Second International Mammoth Conference, Rotterdam, May 16-20 1999. DEINSEA 9. 2003. P.365-379; Willerslev et al. Fifty thousand years of Arctic vegetation and megafaunal diet // Nature. 2014. Vol. 506, no. 7486, 6 February. P. 47-51.

${ }^{26}$ Mol D., Post K., Reumer J. W. F., van der Pflicht J., de Vos J., van Geel B., van Reenen G., Pals J.P., Glimmerveen J. The Eurogeul - first report of the palaeontologica, palynological and archaeological investigations of this part of the North Sea // Quaternary International. 2006. Vol.142-143. P.178-185; Interdisciplinary Archaeological Research Programme Maasvlakte 2, Rotterdam, Part 2. BOORrapporten 566 / eds J. M. Moree, M. M. Sier. 2015. P.357; Peeters H. North Sea Prehistory Research and Management Framework (NSPRMF). Amersfoort, 2009; Glimmerveen J., Mol D., Post K., Reumer J.W.F., van der Plicht H., de Vos J., van Reenen G., Pals J.P. Submarine prehistoric archaeology of the North Sea. Research priorities and collaboration with industry // CBA Research Report 141, English Heritage/Council for British Archaeology. 2004. P. 43-52.

27 Dromgoole S. Underwater Cultural Heritage and International Law. Cambridge, 2013. P. 28-64.

${ }_{28}$ Mol D., de Vos J., Bakker R., van Geel B., Glimmerveen J., van der Plicht H., Post K. Mammoeten, neushoorns en andere dieren van de Noordzeebodem. Veen Magazines. Diemen, 2008.

${ }^{29}$ Glimmerveen J., Mol D., Post K., Reumer J. W. F., van der Plicht H., de Vos J., van Reenen G., Pals J.P. Submarine prehistoric archaeology of the North Sea. Research priorities and collaboration with industry // CBA Research Report 141, English Heritage/Council for British Archaeology. 2004. P. 43-52.

${ }^{30} \mathrm{Mol}$ D., Post K., Reumer J. W. F., van der Pflicht J., de Vos J., van Geel B., van Reenen G., Pals J.P., Glimmerveen J. The Eurogeul - first report of the palaeontologica, palynological and archaeological investigations of this part of the North Sea // Quaternary International. 2006. Vol.142-143. P. 178-185; 


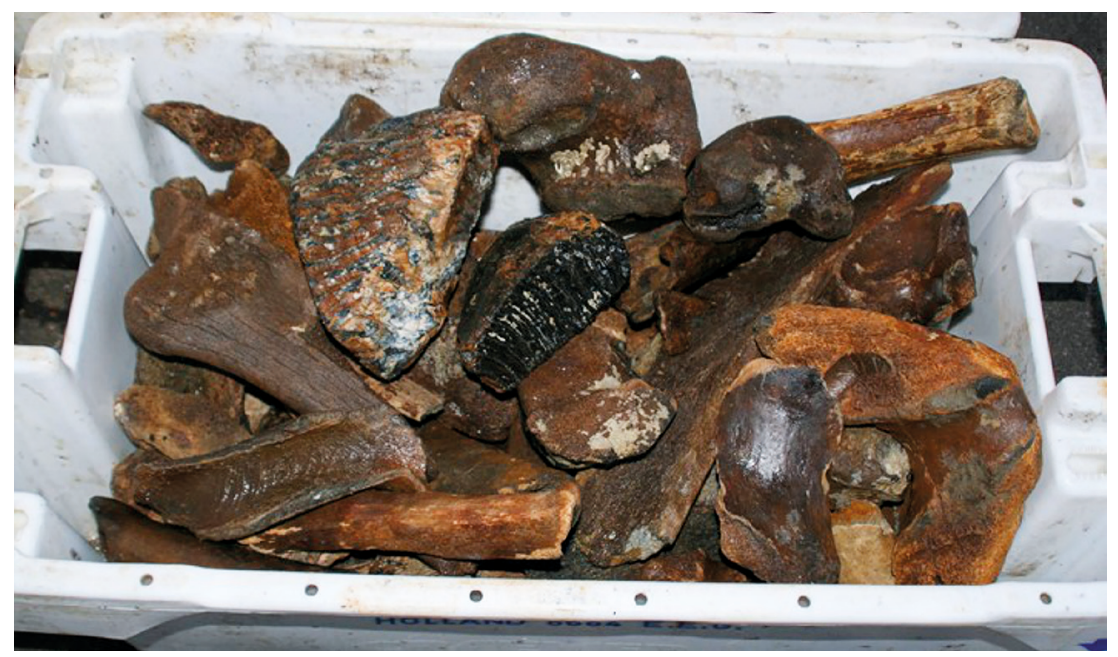

Fig. 3. Example of megafaunal remains trawled up from the North Sea (photo by Jan Meulmeester)

The key questions are: What do these remains of the mammoth fauna represent? Are they from animals that died of natural causes - possibly in so-called 'mammoth cemeteries' - due to natural catastrophes, or were they the prey of prehistoric hunters? Why were they preserved? Unburied bones, including those of the order Proboscidea, i.e. elephants and mammoths that are left unburied on the ground, normally do not survive for long $^{31}$.To what extent do these remains represent material associated with prehistoric settlements where their chances of preservation were significantly improved by, for instance, deposition in pits or other forms of burial? The ability of prehistoric hunter-gatherers to kill prehistoric elephants, including mammoths, has been questioned ${ }^{32}$. This aspect must therefore be investigated as a basis for further discussion.

\section{Ethno-archaeological evidence for human hunting of Elephant/ Mammoth family}

The ethnographic record demonstrates that hunter-gatherers are able to kill Proboscidea. The pygmies of the Congo and Cameroon jungle had no apparent problems in killing elephants with their fire-hardened wooden spears (in a few cases apparently

Interdisciplinary Archaeological Research Programme Maasvlakte 2, Rotterdam. Pt. 2. BOORrapporten 566 / eds J. M. Moree, M. M. Sier. 2015. P. 370, 382.

31 Bell L.S., Skinner M. F., Jones S. J. The speed of post mortem change to the human skeleton and its taphonomic significance // Forensic Science International. 1996. Vol. 82. P. 129-140; Haynes G. Longitudinal Studies of African Elephant Death and Bone Deposits // Journal of Archaeological Science. 1988. Vol.15. P. 131-157; Trueman C.N.G., Behrensmeyer A.K., Tuross N., Weiner S. Mineralogical and compositional changes in bones exposed on soil surfaces in Amboseli National Park, Kenya: diagenetic mechanisms and the role of sediment pore fluids // Journal of Archaeological Science. 2004. Vol.31. P.721-739.

32 Binford L.R. Human Ancestors; Changing Views of Their Behavior // Journal of Anthropological Archaeology. Vol. 4. 1985. P. 292-327; Bosch M. D. Human-Mammoth dynamics in the mid-Upper Paleolithic of the Middle Danube region // Quaternary International. 2012. Vol.276-277. P.170-182; Soffer O. The Upper Paleolithic of the Central Russian Plain. New York, 1985. P. 477. 
tipped with poison) or sometimes with harpoons. These large animals were targeted in their soft underbellies, just behind the ribs, or had their Achilles tendons cut. The aim of the former was to puncture the animal's bladder. Wounds inflicted in this way would leave few traces on the skeleton, and they enabled a single hunter to kill an elephant. The animal would die within a couple of days of the attack, in many cases far away from where it had been speared ${ }^{33}$. Cutting an elephant's Achilles tendons required a group of four to five pygmy hunters, but was also an efficient hunting method, which left the elephant to die where it had been attacked. According to Wæhle, the older pygmies in his study area were also acquainted with pygmy use of spear-falls and self-shot mechanisms, while the younger pygmies were not ${ }^{34}$ (Wæhle personal communication).

According to Schebesta, some Asian Semang (the Ple from Ulu Sengoh/Perak) apparently also hunted elephants for food using foot-traps or spear-falls, even though most of the groups in this area had a food taboo relating to the animals ${ }^{35}$. The Indian Kadar of Cochin trapped elephants for use as presents but did not eat their flesh because of a similar food taboo ${ }^{36}$.

All in all, it seems that hunting Proboscidea apparently posed no problems for either recent pygmy hunter-gatherers or a number of other cultural groups.

\section{Archaeological evidence for human hunting of Elephant/Mammoth family}

The body of archaeological evidence for human hunting of Proboscidea is presently increasing rather rapidly due to a new research focus on this theme. New mammoth sites with evidence for hunting have been found and old sites and finds have been re-examined, resulting in new observations and identifications of traces indicating hunting and butchering.

\subsection{Associated hunting weapons and remains of Proboscidea that indicate hunting}

A fire-hardened wooden (ebony) spear from the Upper Acheulian, found between the ribs of the skeleton of a straight-tusked elephant at Lehringen in Germany, demonstrates that, as has been pointed out by Jacob-Friesen and Movius, spear-hunting techniques like those of pygmy groups/tribes were practised during the Palaeolithic ${ }^{37}$. A clum-

33 Putnam A.E. Eight Years with Congo Pigmies. London, 1955. P.91-96; Turnbull C. M. The Mbuti Pygmies: An Ethnographic Survey // Anthropological Papers of the American Museum of Natural History. Vol. 50, pt. 3. New York 1965. P. 206-207; Zwilling E. A. Unvergessenes Kamerun. Zehn Jahre Wanderungen und Jagden 1928-1938. Berlin, 1941.

34 Turnbull C.M.: 1) The Mbuti Pygmies: An Ethnographic Survey // Anthropological Papers of the American Museum of Natural History, Vol. 50, pt. 3. New York 1965. P. 208; 2) The Mbuti Pygmies. Change and Adaptation. New York, 1983. P. 19-20.

35 Schebesta P. Die Negritos Asiens. II Bd. Etnographie der Negrito. 1. Halbband, Wirtschaft und Soziologie. Mödling, 1954. S. 58.

36 Ehrenfels U.R. Kadar of Cochin. Madras University Anthropological Series, no. I. University of Madras, 1952. P. 17, 57, 71, 110, 112, 180-181.

37 Jacob-Friesen K. H. Grosswildjäger des Eiszeitalters in Niedersachsen. Kosmos, Heft 11. November, 1949. P.408-412; Movius Jr. H.L. A Wooden Spear of Third Interglacial Age from Lower Saxony 
sily-made, roughly-pointed artefact, fashioned from the split long bone of a deer, was found in the more or less articulated skeleton of an enormous forest elephant (calculated head height $4.2 \mathrm{~m}$ ) that had partly sunk into the muddy shore sediments of a prehistoric lake at Neumark-Gröbern, Germany. Clearly associated with this skeleton were also 26 Palaeolithic flint flakes ${ }^{38}$. The authors doubt whether this irregular bone point would have been able to penetrate the $2-3 \mathrm{~cm}$ thick 'leather hide' of the elephant. However, it should be borne in mind that the animal's belly is much less well protected than the rest of its body, making this the ideal point of attack. The tip of what appears to have been a wooden spear of yew, not fire-hardened, was found at Clacton-on-Sea, in a Clactonian flint artefact context, in deposits containing faunal remains that included forest elephant (Elephas antiquus) $^{39}$. An interesting note in Nature (1888) mentions the discovery near Southall, west of London, of a mammoth skeleton surrounded by flint artefacts, including hand axes:

Several implements were found in Norwood Lane, in close proximity to the remains, and a well-formed spear-head, nearly 5 inches in length, of exactly the same shape as the spear-heads of obsidian until recently in use among the natives of the Admiral Islands, and other savages, was discovered in actual contact with the bones; smaller spear-head flakes, less symmetrically worked, were also found at this spot. They are symmetrically formed for easy insertion into the shafts by thinning out the butt ends, similar to those found abundantly by the author at the workshop floor, Acton, and described by him in his recently published work, "Palaeolithic Man in North-West Middlesex" ${ }^{40}$.

\subsection{Projectile impacts and butchering traces}

The increasing number of records of spear, lance and other projectile points, or evidence of the impact of such weapons, found on prehistoric mammoth/elephant skeletons, demonstrates that Proboscidea were hunted by humans during the Palaeolithic. The YMAM site, near the Yana Palaeolithic Site (RHS), in Arctic Siberia, is an accumulation of mammoth bones representing a minimum of 31 individuals, over a period extending from 31,200 to $25,100 \mathrm{BP}$. Of the four projectile impacts recorded there, three had struck three right scapulae and the fourth - a pelvis ${ }^{41}$. At Kostienki I, dated to around $21,000 \mathrm{BP}$, a mammoth rib was found with a tip fragment from a flint point embedded in $\mathrm{it}^{42}$. At Lugovskoe, western Siberia, the skeleton of an adult female mammoth, dating from around $13,500 \mathrm{BP}$, had a penetrating injury to a thoracic vertebra caused by what

// Southwestern Journal of Anthropology. 1950. Vol.6, no.2. P.139-142; Thieme H. Lower Palaeolithic hunting spears from Germany // Nature. 1997. Vol. 385, no. 6619, 27 February. P. 807-810.

${ }_{38}$ Mania D., Thomae M., Litt T., Weber T. Neumark-Grobern. Beitrage zur Jagd des mittelpalaolithischen Menschen. Berlin, 1990. P. 117-121, 215-235.

39 Oakley K.P., Andrews P., Keeley L.H., Clark J.D. A Reappraisal of the Clacton Spearpoint // Proceedings of the Prehistoric Society. 1977. Vol. 43. P.13-30.

40 Brown J. A. Discovery of Elephas Primigenius associated with flint implements at Southall // Nature. 1888. Vol.38, iss.977, July 19. P. 283-284.

${ }^{41}$ Nikolskiy P. A., Pitulko V. V. Evidence from the Yana Palaeolithic site, Arctic Siberia, yields clues to the riddle of mammoth hunting // Journal of Archaeological Science. 2013. Vol.40. P. 4189-4197.

42 Praslov N. Outils de chasse du Paleolithique de Kostenki // Anthropologie et Prehistoire. 2000. Vol.111. P.37; Sinitsyn A.A., Praslov N.D., Svezhentsev Yu.S., Sulerzhitskii L.D. Radiouglerodnaia khronologiia paleolita Vostochnoi Evropy // Radiouglerodnaia khronologiia paleolita Vostochnoi Evropy i Severnoi Azii. Problemy i perspektivy. St. Petersburg, 1997. P.21-66. 
appears to have been a point with two slots for quartzite inserts ${ }^{43}$. In 2011, a concentration of faunal remains, including those of at least five mammoths, was found at the Orto-Stan site on the Buor-Khaya Peninsula, Siberia. Two well-preserved pelvic bones of mammoth showed clear projectile impacts and one of these had clear traces of the removal of the head of the femur with a chopping tool. In addition, a right innominate bone of a horse had distinct cutmarks made by a lithic tool. The three bones with impacts resulting from human activity are dated to 28,790-27,080 $\mathrm{BP}^{44}$. By the Maksunuokha river in Siberia, the Nikita site consists of a redeposited concentration of faunal remains that includes at least 11 individuals. Several mammoth ribs show clear butchering marks, and some have lithic tool fragments embedded in them. The site has been radiocarbon dated to $12,050-11,960 \mathrm{BP}$ and contains ivory debitage, spearhead preforms and actual lithic artefacts including teardrop bifaces ${ }^{45}$. On the Ilin-Syalakh river, in the Yana-Indighirka interfluve, a smaller concentration of mammoth remains, the ISYLAKI-034 site, includes several mammoth ribs with clear human impact traces that can be interpreted as either butchering marks or projectile impacts. A mammoth mandible from this site gave a date of 22,700 $\mathrm{BC}^{46}$. At the Valea Morilor Palaeolithic site, Moldova, a mammoth ulna showed evidence of having been pierced by a pointed weapon ${ }^{47}$. At the Gontsy Palaeolithic site in the Ukraine, a bladelet was found lodged in a mammoth ib $^{48}$. At the Manis Mastodons site, on Washington's Olympic Peninsula, a mastodon skeleton had a point made from a mastodon bone embedded in a 12th, 13th or (most likely) 14th rib; the point has been dated to $13,800 \mathrm{BP}^{49}$.

\subsection{Configurations of Proboscidea remains indicating butchering}

Several Palaeolithic sites have also been found to contain varying concentrations of Proboscidea remains, where the configuration of these bones, their relation to human artefacts, or to bones of other hunted species, cutmarks, bone breakage patterns, the surface conditions and/or the sorting of various skeletal parts etc., strongly indicate that these assemblages represent hunted and butchered animals. Examples include: Dolní Vĕstonice I-II, Pavlov I and Milovice G and IV, the Czech Republic; Geissenklösterlee, Hohle Fels,

${ }^{43}$ Zenin V. N., LeshchinskiyS. V., Zolotarev K. V., Grootes P. M., Nadeau M.-J. Lugovskoe: geoarchaeology and culture of a Paleolithic site // Archaeology, Ethnology and Anthropology of Eurasia. 2006. Vol. 25. P. 4153.

44 Pitulko V. V., Yakshina I., Strauss J., Schirrmeister L., Knzuetsova T., Nikolskiy P., Pavlova E. Y. A MIS 3 kill-butchery mammoth site on Buor-Khaya Peninsula, Eastern Laptev Sea, Russian Arctic // Scientific Annals, School of Geology, Aristotle University of Thessaloniki, Greece, VI ${ }^{\text {th }}$ International Conference on Mammoths and their Relatives, Grevena - Siatista. Special Vol. 102. Thessaloniki, 2014. P. 158-159.

45 Ibid. P. 155.

46 Ibid.

47 Obada T., van der Plicht J., Markova A., Prepelitsa A. Preliminary results of studies of the Valea Morilor Upper Palaeolithic site (Chişinău, Republic of Moldova): A new camp of mammoth hunters // Quaternary International. 2012. Vol.276-277. P.227-241.

48 Iakovleva L., Djindjian F. New data on Mammoth bone settlements of Eastern Europe in the light of the new excavations of the Gontsy site (Ukraine) // Quaternary International. 2005. Vol. 126-128. P. 195207.

49 Lawler A. Pre-Clovis Mastodon Hunters Make a Point. Science Vol.334, 21 October, 2011; Waters M.R., Stafford T.W.jr., McDonald H.G., Gustafson C., Rasmussen M., Cappellini E., Olsen J.V., Szklarczyk D., Jensen L. J., Gilbert T.P., Willerslev E. Pre-Clovis Mastodon Hunting 13,800 Years Ago at the Manis Site, Washington // Science. 2011. Vol.334, 21 October. P. 351-353. 
Krems Wachtberg and the Neumark-Gröbern sites, Germany; Valea Morilor, the Republic of Moldova; the Maastricht-Belvédère Sites (B, C, G, N) and the Veldwezelt-Hezerwater sites (WFL, TL, MLMB), the Netherlands and Belgium; Krakow-Spadzista Street (B), Poland; Yudinovo (pavilion), Kostienki I and YMAM, Russia; Ambrona, Spain; Mezhirich and Gontsy, the Ukraine; La Sena and Lovewell, USA (Nebraska and Kansas) ${ }^{50}$.

Several concentrations of Proboscidea remains have been proclaimed so-called 'mammoth cemeteries' in the sense of 'natural death sites' where single individuals or herds of Proboscidea were caught in natural traps under circumstances that provided good conditions for the preservation of their remains. They are thought to have drowned while crossing rivers, lakes or swamps, to have been covered by falling/sliding earth, stone or other debris or to have fallen into 'permafrost wells' (pot holes, sink holes) that can form as part of subsoil ice veins in permafrost areas, or to have drowned in flash floods ${ }^{51}$.

${ }^{50}$ Fladerer F. A., Salcher-Jedrasiak T. A., Händel M. Hearth-side bone assemblages within the 27 ka BP Krems-Wachtberg settlement: Fired ribs and the mammoth bone-grease hypothesis // Quaternary International - in press - (2012); Germonpré M., Sablin M., Khlopachev G. A., Grigorieva G. V. Possible evidence of mammoth hunting during the Epigravettian at Yudinovo, Russian Plain // Journal of Anthropological Archaeology. 2008. Vol.27. P. 475-492; Hoffecker J. F., Kuz'mina I. E., Syromyatnikova E. V., Anikovich M. V., Sinitsyn A.A. Popov V. V., Holliday V.T. Evidence for kill-butchery events of early Upper Paleolithic age at Kostenki, Russia // Journal of Archaeological Science. 2010. Vol.37. P.1073-1089; Holen S.R. Taphonomy of two last glacial maximum mammoth sites in the central Great Plains of North America: A preliminary report on La Sena and Lovewell // Quaternary International. 2006. Vol.142-143. P. 30-43; Iakovleva L., Djindjian F., Maschenko E. N., Kronik S., Moigne A.-M. The late Upper Palaeolithic site of Gontsy (Ukraine): A reference for the reconstruction of the hunter-gatherer system based on a mammoth economy // Quaternary International. 2012. Vol.255. P. 86-93; Kozlowski J. Mammoth bone accumulations and dwelling structures: discussing some arguments around Krakow-Spadzista B site // Perceived Landscapes and Built Environments. The Cultural Geography of Late Paleolithic Eurasia, BAR International Series. 2003. Vol.1122. P.59-64; Mania D., Thomae M., Litt T., Weber T. NeumarkGrobern. Beitrage zur Jagd des mittelpalaolithischen Menschen. Berlin, 1990. S. 36, 113-114, 117-121, 125-126, 215-235; Münzel S. C. Seasonal hunting of mammoth in the Ach-Valley of the Swabian Jura // The World of Elephants. Proceedings of the $1^{\text {st }}$ International Congress, Rome, 16-20 october, 2001. P.318-322; Nikolskiy P. A., Pitulko V. V. Evidence from the Yana Palaeolithic site, Arctic Siberia, yields clues to the riddle of mammoth hunting // Journal of Archaeological Science. 2013. Vol.40. P.4189-4197; Obada T., van der Plicht J., Markova A., Prepelitsa A. Preliminary results of studies of the Valea Morilor Upper Palaeolithic site (Chişinău, Republic of Moldova): A new camp of mammoth hunters // Quaternary International. 2012. Vol.276-277. P.227-241; Pidoplichko l.G. Upper Palaeolithic Dwellings of Mammoth Bones in the Ukraine // BAR International Series. Oxford, 1998. Vol.712. P. 87-105, 157; Sinitsyn A. A., Stephanova K. N. Models of Landscape use in the Upper Palaeolithic. Geomorphic Processes and Geoarchaeology // From Landscape Archaeology to Archaeotourism. International conference, August 20-24. 2012, Moscow Smolensk, Russia. Extended Abstracts. P.257-260; Svoboda J., Péan S., Wojtal P. Mammoth bone deposits and subsistence practices during Mid-Upper Palaeolithic in Central Europe: three cases from Moravia and Poland // Quaternary International. 2005. Vol. 126-128. P. 209-221; Svoboda J., Bocheński Z. M., Čulíková V., Dohnalová A., Hladilová S., Hložek M., Horáček I., Ivanov M., Králík M., Novák M., Pryor A. J. E., Sázelová S., Stevens R.E., Wilczyński, Wojtal P. Paleolithic Hunting in a Southern Moravian Landscape: The Case of Milovice IV, Czech Republic // Geoarchaeology: An International Journal. 2011, Vol.26, no. 6. P. 838-866; Villa P., Soto E., Santonja M., Pérez-Gonzáles A., Mora R., Parcerisas J., Sesé C. New data from Ambrona: closing the hunting versus scavenging debate // Quaternary International. 2005. Vol.126-128. P.223-250; Warrimont J.P.L.M.N. de. Prospecting Middle Palaeolithic open-air sites in the Dutch-Belgian border area near Maastricht // PalArch's Journal of Archaeology of Northwest Europe 1. 2007. Vol.3. P. 40-89; Wojtal P., Sobczyk K. Taphonomy of the Gravettian site - Kraków Spadzista Street (B) // DEINSEA.2003. Vol.9. P.557-562; Wojtal P., Wilczyński J., Bocheński Z.M., Svoboda J.A. The scene of spectacular feasts: Animal remains from Pavlov I south-east, the Czech Republic // Quaternary International. 2012. Vol.252. P. 122141.

51 Vereshchagin N.K.: 1) The mammoth "cemeteries" of North-East Siberia // Polar Record. 1974. Vol. 17, no. 106. P. 3-12; 2) Berelekh mammoth graveyard (in Russian) // Trudy Zoologicheskogo instituta. 
In an attempt to distinguish between assemblages of mammoth/elephant remains resulting from hunting by humans and natural causes of death, Germonpré compares two archaeological sites likely to belong to the first category, Yudinovo ('pavilion' - complexes 3 and 4) and Krakow-Spadzista Street, with concentrations of remains as high as one individual per 1.4-1.9 $\mathrm{m}^{2}$, with two modern African natural death sites where densities are markedly lower, ranging from one elephant individual per 6-35 $\mathrm{m}^{2}$. The individuals found at the latter sites tend also to be significantly younger than those in the assemblages resulting from (presumed) human activities: At least $85 \%$ of the individuals at the two African natural death sites were less than 12 years of age when they died, whereas the average age of the individuals from the archaeological sites was considerably greater ${ }^{52}$. Account should be taken of the fact that the two natural death sites in Africa were both in places where elephants tend to sink into the mire. Consequently, young, weaker individuals would be more exposed to danger than older, stronger ones. Natural death sites representing herds that were covered by landslides can, on the other hand, be expected to have a different age profile. However, distinguishing between different site types, based on the age-at-death profiles of the animals involved appears more complicated than stated by Klein. Moreover, in addition to the fact that different types of natural death sites must be expected to produce different age-at-death profiles, the potential coexistence of various well-established hunting strategies further complicates the matter. This is demonstrated by Bosch's study of five mammoth bone assemblages in cultural deposits at four archaeological sites in the Middle Danube region ${ }^{53}$. Detailed studies of the presence/absence of small foot bones, sorting of specific skeletal parts and the degradation of bone surfaces appear to yield more reliable information about which category a bone assemblage belongs to ${ }^{54}$.

The classic 'mammoth cemetery' in the North Yakutian locality of Berelekh was investigated extensively by Vereshchagin in 1970-1972. The excavation uncovered the remains of 140 mammoth individuals deposited in a palaeochannel. They are presumed to have died in small groups along the upper reaches of the proto-Berelekh river, killed either by winter blizzards or by drowning in spring or autumn when crossing the ice or by one or more flash-flood events. The use of 'powerful jets of water' in the excavation may have resulted in the loss of Palaeolithic artefacts. The recovery of only 39 tusks is taken to reflect that some tusks were salvaged from the site by Palaeolithic hunters. The central

1977. Vol.72. P.5-50; Vereshchagin N. K., Tomirdiaro S. V. Taphonomic research in permafrost regions: a survey of past and present studies in the former Soviet Union // Mammoths and the Mammoth Fauna: Studies of an Extinct Ecosystem. DEINSEA.1999. Vol.6. P.187-198; Nikolskiy P.A., Basilyan A.E., Sulerzhitskya L.D., Pitulko V. V. Prelude to the extinction: Revision of the Achchagyi-Allaikha and Berelyokh mass accumulations of mammoth // Quaternary International. 2010. Vol.219. P. 16-25.

52 Corfield T.F. Elephant mortality in Tsavo National Park // East African Wildlife Journal 11. 1973. P.339-368; Germonpré M., Sablin M., Khlopachev G. A., Grigorieva G. V. Possible evidence of mammoth hunting during the Epigravettian at Yudinovo, Russian Plain // Journal of Anthropological Archaeology. 2008. Vol.27. P.475-492; Haynes G. Mammoths, Mastodonts, and Elephants. Biology, Behavior, and the Fossil Record. Cambridge, 1991. Tables 4.6-4.7.

53 Bosch M.D. Human-Mammoth dynamics in the mid-Upper Paleolithic of the Middle Danube region // Quaternary International. 2012. Vol.276-277. P.170-182; Klein R. G. Age (Mortality) Profiles as a Means of Distinguishing Hunted Species from Scavenged Ones in Stone Age Archeological Sites // Paleobiology. 1982. Vol. 8, no. 2 (Spring, 19132). P. 151-158.

54 Germonpré M., Sablin M., Khlopachev G.A., Grigorieva G.V. Possible evidence of mammoth hunting during the Epigravettian at Yudinovo, Russian Plain // Journal of Anthropological Archaeology. 2008. Vol. 27. P. 475-492. 
question here is whether the dating of the bone bed to the interval 13,700-11,900 years $\mathrm{BP}$ is matched by the local presence of hunters. The Palaeolithic cultural deposits recorded $150 \mathrm{~m}$ downstream from the bone bed are dated to c. 12,000-11,500 years BP. However, unstratified finds of bone artefacts found in the area have yielded dates of 11,800 , 12,200 and 18,920 years BP respectively, indicating that human presence locally may not have been restricted to the period represented by the cultural deposits first recorded in the area ${ }^{55}$. The fact that natural disasters, such as those suggested by Vereshchagin, may have resulted in the deposition in a palaeochannel of concentrations of mammoth skeletons of this magnitude within such a restricted area is intriguing.

Another important and extensively investigated mammoth mass death site is that at Sevsk, on the central Russian Plain, $600 \mathrm{~km}$ south of Moscow, which was excavated in 1988-91. The site, which is interpreted as resulting from a number of mammoths being caught by landslides, consisted of two spatially-connected lenses of alluvial sand and clay, $20 \mathrm{~m}$ long, 6-7 m wide and 30-50 cm thick. The lower lens contained all the articulated skeletons from a minimum of 33 individuals, as well as sixteen pieces of worked flint directly associated with the concentration of bones, which show no cutmarks, while the upper lens only contained isolated bones ${ }^{56}$. The age and sex distribution of the materials resemble those of modern elephant family groups and is very similar to the situation at Berelekh. The presence of articulated skeletons and small foot bones is taken as indicating that these mammoths died in situ. The dating interval for the bones from the lower bone-bearing lens is quite narrow: c. 13,950 years BP, whereas a tusk from the upper bone-bearing lens has been dated to 13,680 years $\mathrm{BP}^{57}$. It seems strange, however, that a group of 33 mammoths, including quite a number of strong, adult individuals, could be caught and killed by a landslide that deposited little more than $30-50 \mathrm{~cm}$ of sand, at the most. The bottom of the lower sand lens, as presented in the published section, seems to show local pit/depression features related to the visible skeletons (Fig. 4) ${ }^{58}$. The dimensions of the lower lens, $6-7 \times 20 \mathrm{~m}$, correspond to c. $4 \mathrm{~m}^{2}$ per mammoth individual. This is not much more than the area occupied by individual elephants pressed against each other and is very different from the spatial situations observed when screening a large number of photos of elephant herds where the animals are generally seen to be several metres apart. It is difficult to find scientific data on the maximum density of these herds. The minimum indoor space per elephant recommended by the Association of Zoos and Aquariums (AZA) is, however, $56 \mathrm{~m}^{2}$ for males, $37 \mathrm{~m}^{2}$ females and $56 \mathrm{~m}^{2}$ for females with calves $^{59}$.

${ }^{55}$ Pitulko V. V. The Berelekh Quest: A Review of Forty Years of Research in the Mammoth Graveyard in Northeast Siberia // Geoarchaeology. 2011. Vol.26, no. 1. P. 5-32; Pitulko V. V., Basilyan A. E., Pavlova E. Y. The Berelekh Mammoth "Graveyard": New Chronological and Stratigraphical Data from the 2009 Field Season // Geoarchaeology. 2014. Vol.29. P.277-299; Vereshchagin N.K.: 1) The mammoth 'cemeteries' of North-East Siberia // Polar Record. 1974. Vol.17, no.106. P.3-12; Berelekh mammoth graveyard (in Russian) // Trudy Zoologicheskogo instituta. 1977. Vol. 72. P. 5-50.

${ }_{56}$ Maschenko E.N., Gablina S.S., Tesakov A.S., Simakova A.N. The Sevsk woolly mammoth (Mammuthus primigenius) site in Russia: Taphonomic, biological and behavioral interpretations // Quaternary International. 2006. Vol.142-143. P. 147-165, fig. 2B.

57 Ibid. P. 147-165.

58 Ibid. Fig. 2B.

59 Associations of Zoos \& Aquariums: AZA Standards for Elephant Management and Care. Approved March 2011. 


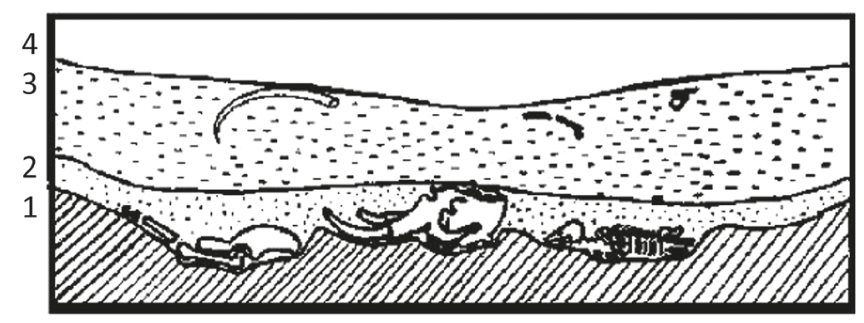

Fig. 4. Vertical section through the excavation at Sevsk:

1 - Alluvial sand deposits underlying the bone-bearing lenticular layer; 2 - The lower bone-bearing lenticular layer, 30-50 cm thick, containing well-preserved bones, skeletons and skeletal fragments; 3 - The upper part of the bonebearing lenticular layer with isolated bones does not contain any complete skeletons or skeletal fragments; 4 - Deposits overlaying the bone-bearing layer [Maschenko, 2006, fig. 2B]

A third possible "mammoth cemetery" is the north Siberian site of Achchagyi-Allaikha, located $125 \mathrm{~km}$ to the east of the Berelokh locality. The site was discovered in the early 1970s in the side of the Achchagyi-Allaikha channel. It was partially excavated in 1982, with further investigation in 2003-04. All the faunal remains recovered so far represent material redeposited from one or more layers located higher up in the channel side. The distribution of the material is restricted to a $30-40 \mathrm{~m}$ zone along the channel. The mammoth remains include small bones, but no intact tusks, complete skulls or lower jaws and only a few isolated teeth. This situation probably reflects the easy accessibility of the site, and extraction of tusks, teeth and occasionally also large bones is known to have taken place (at times through large-scale excavation) with the involvement of local people from the Chokurdal settlement located $20 \mathrm{~km}$ away. A MNI (minimum number of individuals) of 21 individuals from the most recent campaign may overlap to some degree with the MNI of 14 individuals recovered in the first excavation. In terms of age and gender, the remains recovered during the most recent campaign match the composition of family groups of modern elephants. The material is coeval with Berelekh, with radiocarbon dates covering the interval from 12,500 to 12,300 years BP. Even though a few stone tools (two bifaces and a flake) were found during the 1982 excavation, prehistoric human activity at the site is thought to have been restricted to scavenging for tusks. As for the cause of death of these mammoths, it is suggested that early spring flooding (possibly aggravated by ice drift) was responsible ${ }^{60}$. Again, it is rather difficult to understand how flooding could have led to the formation of such a small, spatially restricted concentration of bones.

It is worth noting that several Russian researchers have, in recent years, become increasingly accepting of the general idea of humans as central agents in the creation of mammoth bone concentrations ${ }^{61}$.

${ }^{60}$ Nikolskiy P. A., Basilyan A.E., Sulerzhitskya L.D., Pitulko V.V. Prelude to the extinction: Revision of the Achchagyi-Allaikha and Berelyokh mass accumulations of mammoth // Quaternary International. 2010. Vol.219. P. 16-25.

${ }^{61}$ Pitulko V. V., Nikolskiy P. A., Basilyan A. E., Pavlova E. Y. Dating mass accumulations of mammoth across Arctic Eurasia // The Quaternary in all of its variety. Basic issues, results, and major trends of further 
Based on evidence from the Gontsy site, Iakovleva et al. ${ }^{62}$ describe the typical position of a mammoth-hunter base camp from the end of the Weichselian glaciation - around $15,000-14,000 \mathrm{BP}$ - in the landscape, as well as the spatial 'modules' that appear to make up such sites. They are generally located on promontories bordered by ravines cut into the slopes of river valleys and generally consist of:

A. An area with mammoth-bone huts and associated pits (up to ten pits around each hut) and other related structures, separated by zones of working areas with hearths.

B. Dump areas with remains of hearth debris and flint debitage.

C. Butchering areas used specifically for small and medium-sized mammals (reindeer, carnivores and rodents)

D. A mammoth 'bone bed' typically located in a palaeo-ravine not far from the other settlement modules. This can contain bones of other mammals, hearths and artefacts of bone and flint apparently reflecting exploitation of the bone bed. The content of the latter shows an under-representation of the scapulae, pelvises, skulls, tusks, long bones and jaws typically found in mammoth-bone huts.

It must of course be expected that other, less visible, types of site were employed by the same cultures responsible for these highly visible localities and that there was considerable variation over time in this site organisation pattern. What is interesting, however, is the concept of a separate bone bed being an integral part of these massive settlements, serving as a storage facility for larger, more or less articulated, parts of mammoths (reflected in the presence of ribs, vertebrae and distal leg bones). The meat was for consumption and the extremely fat-rich Proboscidea bones were used for fuel - a widely recognised practice in the mammoth-hunter cultures of the last glaciation ${ }^{63}$.

Even in an Arctic climate, the bodies of larger animals left unprotected on the surface must be assumed to have become unsuitable for human consumption within a few days, as a result of chemical-bacterial degradation, in addition to the more useful parts being removed by scavengers ${ }^{64}$. In general, the actual bones would disappear rather quickly due to the actions and effects of rodents, fungi, sun and rain. Even a relatively rapid loess deposition of several centimetres per year, forming 'dunes' around the dead bodies, as suggested by Vereshchagin, is unlikely to have preserved the skeletons ${ }^{65}$.

research. Proceedings of the VII All-Russian Quaternary Conference (Apatity, September 12-17, 2011), Vol. 2. The Geological Institute KSC RAS. 2011. P. 146-149.

${ }^{62}$ Iakovleva L., Djindjian F., Maschenko E. N., Kronik S., Moigne A.-M. The late Upper Palaeolithic site of Gontsy (Ukraine): A reference for the reconstruction of the hunter-gatherer system based on a mammoth economy // Quaternary International. 2012. Vol.255. P. 86-93.

63 Iakovleva L., Djindjian F., Maschenko E. N., Kronik S., Moigne A.-M. The late Upper Palaeolithic site of Gontsy (Ukraine): A reference for the reconstruction of the hunter-gatherer system based on a mammoth economy // Quaternary International. 2012. Vol.255. P. 86-93; Marquer L., Otto T., Nespoulet R., Chiotti L. A new approach to study the fuel used in hearths by hunter-gatherers at the Upper Palaeolithic site of Abri Pataud (Dordogne, France) // Journal of Archaeological Science. 2010. Vol.37. P. 2735-2746; Praslov N.D., Stanko V. N., Abramova Z. A., Sapozhnikov I. V., Brozijak I. A. The steppes in the Late Palaeolithic // Antiquity. 1989. Vol.63(241). P. 784-792; Soffer O. The Upper Paleolithic of the Central Russian Plain. New York, 1985. P. 258-259.

${ }^{64}$ Haynes G. Longitudinal Studies of African Elephant Death and Bone Deposits // Journal of Archaeological Science. 1988. Vol. 15. P. 131-157.

65 Vereshchagin N. K. The mammoth "cemeteries" of North-East Siberia // Polar Record. 1974. Vol. 17, no. 106. P. 3-12. 
The assumption is that these bone beds, in many cases representing permafrost-based meat stores in the vicinity of base camps, containing large chunks of Proboscidea meat deposited in palaeo-ravines and palaeochannels and covered by insulating sediment, combined with burning of the bones following subsequent processing and consumption of this meat, can explain the good preservation of the material, as well as the very restricted appearance of cutmarks on the large quantities of preserved Proboscidea bones. In this respect, it is interesting that the ravine containing the bone bed at Gontsy was apparently rapidly filled with up to $75 \mathrm{~cm}$ of sand and silt. The absence of evidence of gnawing by carnivores or weathering indicates that its contents were not left exposed to the open air ${ }^{66}$. This may not be a natural but a cultural phenomenon.

The bone beds at Dolní Vĕstonice I and II showed some degree of sorting of articulated rib elements, vertebrae and groups of carpals/tarsals, whereas in the bone bed at Gontsy these skeletal elements in some cases appeared in 'anatomical groups', interpreted as representing parts of individual animals ${ }^{67}$. These observations support the interpretation of the bone beds as storage facilities.

The Sevsk bone bed, which includes ribs, vertebrae and carpals/tarsals, as well as skulls and tusks that do not normally appear in settlement bone beds, could hypothetically represent a storage facility for entire mammoth individuals.

\section{Back to the North Sea - discussion}

The above discussion demonstrates the massive extent of human hunting of Proboscidea during the Late Weichselian glaciation and suggests that a major proportion of the preserved bones and tusks from these animals may owe its preservation to artificial deposition in permafrost-based storage facilities or use as structural materials for dwellings and other constructions. For example, at Kostienki I, the tusks used to support the roofs over the dwelling pits were, following their collapse, protected by the fill within these pits $^{68}$.

In a discussion of the actual significance and origin of the abundant mammoth remains recovered from the Danish, German, British and Dutch North Sea sectors, the possibility that a significant proportion of these represent bones and tusks preserved because they were associated with settlements and/or kill-site storage facilities, based on an updated understanding of land-based Eurasian mammoth and mammoth-hunter sites, seems much more plausible than hitherto assumed. In principle, the majority of the Proboscidea remains trawled up from the North Sea may represent human settlement material.

A general problem that apparently prevents proper archaeological interpretation of the mammoth faunal remains from the North Sea, as well as a large proportion of the east-

${ }^{66}$ Iakovleva L., Djindjian F., Maschenko E. N., Kronik S., Moigne A.-M. The late Upper Palaeolithic site of Gontsy (Ukraine): A reference for the reconstruction of the hunter-gatherer system based on a mammoth economy // Quaternary International. 2012. Vol.255. P. 86-93.

67 Ibid; Svoboda J., Péan S., Wojtal P. Mammoth bone deposits and subsistence practices during MidUpper Palaeolithic in Central Europe: three cases from Moravia and Poland // Quaternary International. 2005. Vol. 126-128. P. 209-221; Wojtal P., Sobczyk K. Taphonomy of the Gravettian site - Kraków Spadzista Street (B) // DEINSEA. 2003. Vol. 126-128. P. 557-562.

68 Praslov N.D., Rogachev A. N. (eds.) Palaeolithic of the Kostenko-Borshchevo area on the river Don. 1879-1979: Results of field investigations (in Russian). Leningrad, 1982. P. 45, 48-49. 
ern "Mammoth-cemeteries", is that they have long been regarded primarily as zoological phenomena. Their full archaeological potential has only recently begun to become clear.

Many modern elephant populations are known to embark on seasonal or periodic long-distance migrations within their 'home ranges'. The home range of a population extends over an area of about 1000 to $9000 \mathrm{~km}^{2}$ and is often centred on a significant river or lake basin. A rough estimate of the size of similar home-range populations in an undisturbed 'pre-agricultural' environment is of the order of 500 animals. Movement is in herds of varying size, from a few individuals to several hundred animals, organised in a hierarchy of families, bond groups and clans ${ }^{69}$. Isotope studies indicate that prehistoric elephant species also exhibited migratory behaviour ${ }^{70}$, most likely of the same kind as today's elephants.

The fact that no classic mammoth-hunter camps have so far been identified in Scandinavia may well be due to these being located on the major prehistoric rivers here, which are today all found below sea level.

Scandinavia's now submerged North Sea coastal zones and hinterlands of glacial and other colder periods may well represent an important research potential with respect to both local cultural developments and the environmental settings in which these took place. It is important to bear in mind that we should not only be aware of the potential for submerged settlements from the Weichselian glaciation, but also from earlier glacial periods. The immediate expectation is, however, that it may be possible to obtain information on actual tangible submerged mammoth hunter sites dating from the later Weichselian period, which are located in the southern part of the Scandinavian North Sea sector, where mammoth fauna remains, including parts of Proboscidea, are known to have been found.

In order to enter this field of research in a meaningful way, we need new and cost-effective methodologies for the mapping, management and investigation of submerged Stone Age landscapes as alternatives to our present relatively inefficient early-phase approaches that are mainly based on topographical modelling which ignores the significant dynamics of the vegetation and fauna ${ }^{71}$.

${ }^{69}$ Jachmann H. Direct Counts of Elephants From the Ground (Chapter 6) // Studying Elephants. AWF Technical Handbook Series. Nairobi, Kenya. 1996. P. 49-56; Smit I. P. L., Grant C. C., Whyte I. J. Landscapescale sexual segregation in the dry season distribution and resource utilization of elephants in Kruger National Park, South Africa // Biodiversity Research. 2007. Vol.13. P. 225-236; Thomas B., Holland J.D., Minot E. Seasonal home ranges of elephants (Loxodonta africana) and their movements between Sabi Sand Reserve and Kruger National Park // African Journal of Ecology (earlier: East African Wildlife Journal). 2011. Vol.50, iss. 4. P.131-139; Western D., Lindsay W. K. Seasonal herd Dynamics of a Savanna Elephant Population. African Journal of Ecology (earlier: East African Wildlife Journal). 1984. Vol. 22, iss. 4. P.229244; Whyte I. J. Studying Elephant Movements (Chapter 8) // Studying Elephants. AWF Technical Handbook Series. Nairobi, Kenya. 1996. P.75-89; Wittemyer G. W., Getz W. M., Vollrath F., Douglas-Hamilton I. Social dominance, seasonal movements, and spatial segregation in African elephants: a contribution to conservation behaviour // Behavioral Ecology and Sociobiology. 2007. Vol. 61, no. 12 (October). P. 1919-1931.

${ }^{70}$ Hoppe K.A. Late Pleistocene mammoth herd structure, migration patterns, and Clovis hunting strategies inferred from isotopic analyses of multiple death assemblages // Paleobiology. 2004. Vol.30(1). P. 129-145; Hoppe K.A., Koch P.L., Carlson R.W., Webb S.D. Tracking mammoths and mastodons: Reconstruction of migratory behavior using strontium isotope ratios // Geology. 2012. Vol.27, no. 5. P. 439442; Sharp Z. D., Atudorei V., Panarello H. O., Fernández J., Douthitt C. Hydrogen isotope systematics of hair: archeological and forensic applications // Journal of Archaeological Science. 2003. Vol. 30. P. 1709-1716.

${ }^{71}$ Bicket A. Submerged Prehistory: Marine ALSF Research in Context. Marine ALSF Science Monograph Series No. 5. (Ed. J. Gardiner). MEPF 10/P150. 2011; Submarine prehistoric archaeology of the North Sea. Research priorities and collaboration with industry // CBA Research Report 141. English Heritage/Council for British Archaeology / ed. by N. Flemming. 2004; Grøn O. Some problems with modelling 
Before the first systematic excavations in Baltic waters documented well-preserved submerged Mesolithic settlement surfaces and associated waste accumulations ${ }^{72}$, there was a robust and widespread view that no settlement deposits could have survived the wave action inherent in marine transgressions. Large areas will of course have been damaged by erosion, for example the central parts of many sounds and belts, but this is not necessarily the general case. Even though the North Sea is more dynamic than the Baltic, we must also expect preserved pockets to be here, in locations protected by bathymetric features. Many of the faunal remains that have been fished up are so well preserved that it is obvious they have not been exposed to dynamic sediment processes.

\section{References}

Alden Smith E., Hill K., Marlowe F. W., Nolin D., Wiessner P., Gurven M., Bowles S., Mulder M. B., Hertz T., Bell A. Wealth Transmission and Inequality among Hunter-Gatherers. Current Anthropology. Vol. 51 (1), feb. 2010, pp. 19-34.

Andersen S. H. Tybrind Vig. Submerged Mesolithic settlements in Denmark. Jutland Archaeological Society Publications., Højbjerg, Aarhus University Press, 2013, vol. 77.

Armand L. K., Leventer A. Palaeo Sea Ice Distribution - Reconstruction and Palaeoclimatic Significance. Sea Ice. An Introduction to its Physics, Chemistry, Biology and Geology. Eds D. N. Thomas \& G. S. Dieckmann. Oxford, Blackwell Publishing, 2003, pp. 333-372.

Austin W.E. N., Hibbert F. D., Rasmussen S. O., Peters C., Abbot P. M., Bryant C. L. The synchronization of palaeoclimatic events in the North Atlantic region during Greenland Stadial 3 (ca 27.5 to $23.3 \mathrm{kyr}$ b2k). Quaternary Science Reviews, 2012, vol. 36, pp. 154-164.

Tjeerd H. van Andel, Davies W. Neanderthals and modern humans in the European landscape during the last glaciation: archaeological results of the Stage 3 Project. Glacial Environments II: Reconstructing the Climate of Europe in the Last Glaciation. Eds E. Barron, T. H. van Andel, D. Pollard. University of Cambridge, McDonald Institute for Archaeological Research, 2003, pp. 57-78.

Bell L. S., Skinner M. F., Jones S. J. The speed of post mortem change to the human skeleton and its taphonomic significance. Forensic Science International, 1996, vol. 82, pp. 129-140.

Bicket A. Submerged Prehistory: Marine ALSF Research in Context. Marine ALSF Science Monograph Series No. 5. (Ed. J. Gardiner). MEPF 10/P150. 2011.

Binford L. R. Human Ancestors; Changing Views of Their Behavior. Journal of Anthropological Archaeology, 1985, vol. 4, pp. 292-327.

Birket-Smith K. The Chugach Eskimo. Copenhagen, Nationalmuseets Publikationsfond, 1953. 252 p.

Bjerck H. B. Tidligmesolittsk tid (TM) og Fosnatradisjon 9500-8000 BC. Ormen Lange Nyhamnia. NTNU Vitenskapsmuseets arkeologiske undersøkelser. Eds H. B. Bjerck, L. I. Åstveit, J. Gundersen, S. Normann. Trondheim, Tapir Akademisk Forlag, 2008, pp. 552-570.

the positions of prehistoric hunter-gatherer settlements on the basis of landscape topography. Journal of Archaeological Science: Reports. Vol.20. 2018. P. 192-199; Grøn O., Boldreel L. O. Chirping for LargeScale Maritime Archaeological Survey. A Strategy Developed from a Practical Experience-Based Approach // Journal of Archaeology. 2014. Vol. Article ID 147390. 2014; Grøn O., Dell'Anno A., Hermand J.-P. Investigations of deep, submerged Stone Age settlements covered by sea-floor sediments: preliminary methodological considerations // IEEEXplore. 2013. P.1-4; Grøn O., Boldreel L.O., Hermand J.-P., Rasmussen H., Dell'Anno A., Cvikel D., Galili E., Madsen B., Nørmark E. Detecting human-knapped flint with marine high-resolution reflection seismics. A preliminary study of new possibilities for sub-sea mapping of submerged Stone Age sites // Underwater Technology. 2018. Vol.35(1); Hermand J.-P., Grøn O., Asch M., Ren Q.-Y. Modelling flint acoustics for detection of submerged Stone Age sites // Proc. OCEANS'11 MTS/ IEEE Kona Conf. (Oceans of Opportunity: International cooperation and partnership across the Pacific). Institute of Electrical and Electronics Engineers, IEEE. Sept. 2011; Hermand J.-P., Tayong R. Geoacoustic characterization of Stone Age cultural layers: Preliminary FE modelling // IEEEXplore. 2013. P. 1-6.

72 Andersen S. H. Tybrind Vig. Submerged Mesolithic settlements in Denmark // Jutland Archaeological Society Publications. 2013. Vol.77; Skaarup J., Grøn O. Møllegabet II. A submerged Mesolithic settlement in southern Denmark. BAR International Series 1328. Oxford, 2004. 
Bjerck H. B. Colonising seascapes: comparative perspectives on the development of maritime relations in the Pleistocene/Holocene transition in north-west Europe. Mesolithic Horizons. Eds S. McCartan, R. Schulting, G. Warren, P. Woodman. Oxford, Oxbow, 2009, pp. 16-23.

Black L. The Nivkh (Gilyak) of Sakhalin and the Lower Amur. Arctic Anthropology, 1973, vol.10(1), pp. $1-110$.

Bordes F. The Old Stone Age. Toronto, World University Library, New York, McGraw-Hill Book Company, 1972.

Bosch M.D. Human-Mammoth dynamics in the mid-Upper Paleolithic of the Middle Danube region. Quaternary International, 2012, vol. 276-277, pp. 170-182.

Bradley B., Stanford D. The North Atlantic ice-edge corridor: a possible Palaeolithic route to the New World. World Archaeology, 2004, vol.36(4), pp. 459-478.

Brown J.A. Discovery of Elephas Primigenius associated with flint implements at Southall. Nature, 1888, July 19 , pp. 283-284.

DeMaille R. J., Sturtevant W. C. Handbook of North American Indians. Plains. Vol. 13. Washington, Smithsonian Institution, 2001, pp.300-312.

Clark J. G. D. Prehistoric Europe. The Economic Basis. London, Methuen \& Co., 1952.

Clark C. D., Hughes A. L. C., Greenwood S. L., Jordan C., Sejrup H. P. Pattern and timing of retreat of the last British-Irish Ice Sheet. Quaternary Science Reviews, 2012, vol. 44, pp. 112-146.

Coles B. Doggerland: a Speculative Survey. Proceedings of the Prehistoric Society, 1988, vol.64, pp. 45-81.

Coles J. M., Higgs E. S. The Archaeology of Early Man. Harmondsworth, Penguin Books Ltd., 1975.

Corfield T. F. Elephant mortality in Tsavo National Park. East African Wildlife Journal, 1973, vol. 11, pp. 339368.

Dansgaard W., White J.W.C., Johnsen S. J. The abrupt termination of the Younger Dryas climate event. Nature, vol. 339, 15 june, 1989, pp. 532-534.

Dromgoole S. Underwater Cultural Heritage and International Law. Cambridge, Cambridge University Press, 2013, $440 \mathrm{p}$.

Ehrenfels U. R. Kadar of Cochin. Madras, University of Madras, 1952, 319 p.

Fischer A. Submerged Stone Age - Danish examples and North Sea potential. Submarine prehistoric archaeology of the North Sea. Research priorities and collaboration with industry. Ed. by Nic Flemming. CBA Research Report 141. English Heritage/Council for British Archaeology, 2004, pp. 23-36.

Fischer A., Mortensen M. F., Henriksen P. S., Mathiassen D. R., Olsen J. Dating the Trollesgave site and the Bromme culture - chronological fix-points for the Lateglacial settlement of Southern Scandinavia. Journal of Archaeological Science, 2013, vol. 40, pp. 1-12.

Fischer A., Clemmesen L. B., Donahue R., Heinemeier J., Lykke-Andersen H., Lysdal P., Mortensen M.F., Olsen J., Vang Petersen P. Late Palaeolithic Nørre Lyngby - a northern outpost close to the west coast of Europe. Quartär, 2013, vol.60, pp.137-162.

Fitzgerald R. T., Jones T.L., Schroth A. Ancient long-distance trade in Western North America: new AMS radiocarbon dates from Southern California. Journal of Archaeological Science, 2005, vol. 32, pp. 423434.

Flemming N. (ed.) Submarine prehistoric archaeology of the North Sea. Research priorities and collaboration with industry. CBA Research Report 141. English Heritage/Council for British Archaeology, 2004.

Flemming N. Research Infrastructure for Systematic Study of the Prehistoric Archaeology of the European Submerged Continental Shelf. Submerged Prehistory. Eds. J. Benjamin, C. Bonsall, C. Pickard, A. Fischer. Oxford; Oakville, Oxbow, 2011, pp. 287-297.

Germonpré M., Sablin M., Khlopachev G. A., Grigorieva G. V. Possible evidence of mammoth hunting during the Epigravettian at Yudinovo, Russian Plain. Journal of Anthropological Archaeology, 2008, vol.27, pp. 475-492.

Gildor H., Tziperman E. Sea ice as the glacial cycles' climate switch: Role of seasonal and orbiting forcing. Paleoceanography, 2000, vol. 15(6), pp. 605-615.

Flemming N. Submarine prehistoric archaeology of the North Sea. Research priorities and collaboration with industry. Eds J. Glimmerveen, D. Mol, K. Post, J. W. F. Reumer, H. van der Plicht, J. de Vos, G. van Reenen, J.P.Pals. CBA Research Report 141, English Heritage/Council for British Archaeology, 2204, pp. 43-52.

Golden K. M. Climate Change and the Mathematics of Transport in Sea Ice. Notices of the American Mathematical Society, 2009, vol. 56(5), pp. 562-584.

Grindon A. J., Davison A. Irish Cepaea nemoralis Land Snails Have a Cryptic Franco-Iberian Origin That Is Most Easily Explained by the Movements of Mesolithic Humans. PLoS ONE, 2013, vol. 8(6), e65792. https://doi.org/10.1371/journal.pone.0065792. 
Grøn O. Our grandfather sent the elk — some problems for hunter-gatherer predictive modelling. Quartär 2012, vol. 59, pp. 175-188.

Grøn O. Some problems with modelling the positions of prehistoric hunter-gatherer settlements on the basis of landscape topography. Journal of Archaeological Science: Reports, 2018, vol. 20, pp. 192-199.

Grøn O., Turov M., Klokkernes T. Settling in the landscape - settling the land: Ideological aspects of territoriality in a Siberian hunter-gatherer society. Archaeology of Settlements and Landscape in the North. Ed. by Anders Olofsson. Umeå, Umeå University, 2008, pp. 57-80.

Grøn O., Froberg M.L. Stone Age in the Danish North Sea Sector. Maritime Archaeology Newsletter from Denmark, 2011, no. 26 (summer), pp. 3-8.

Grøn O., Dell'Anno A., Hermand J.-P. Investigations of deep, submerged Stone Age settlements covered by sea-floor sediments: preliminary methodological considerations. MTS/IEEE OCEANS - Bergen. Bergen, 2013, pp. 1-4. https://doi.org/10.1109/OCEANS-Bergen.2013.6608026

Grøn O., Boldreel L. O. Chirping for Large-Scale Maritime Archaeological Survey. A Strategy Developed from a Practical Experience-Based Approach. Journal of Archaeology, vol.2014, Article ID 147390, 11 p. http://dx.doi.org/10.1155/2014/147390

Grøn O., Boldreel L.O., Hermand J.-P., Rasmussen H., Dell'Anno A., Cvikel D., Galili E., Madsen B., Nørmark E. Detecting human-knapped flint with marine high-resolution reflection seismics. A preliminary study of new possibilities for sub-sea mapping of submerged Stone Age sites. Underwater Technology, 2018, vol. 35, no. 2, pp. 35-49.

Haynes G. Longitudinal Studies of African Elephant Death and Bone Deposits. Journal of Archaeological Science, 1988, vol. 15, pp. 131-157.

Haynes G. Mammoths, Mastodonts, and Elephants. Biology, Behavior, and the Fossil Record. Cambridge University Press, Cambridge, 1991, $413 \mathrm{p}$.

Hermand J.-P., Grøn O., Asch M., Ren Q.-Y. Modelling flint acoustics for detection of submerged Stone Age sites. Proc. OCEANS'11 MTS/IEEE Kona Conf. (Oceans of Opportunity: International cooperation and partnership across the Pacific), Institute of Electrical and Electronics Engineers, IEEE, Sept. 2011/ 0-933957-39-8 @2011 MTS.

Hermand J.-P., Tayong R. Geoacoustic characterization of Stone Age cultural layers: Preliminary FE modelling. IEEEXplore, 2013, pp. 1-6. https://doi.org/10.1109/OCEANS-Bergen.2013.6608184.

Hoppe K. A. Late Pleistocene mammoth herd structure, migration patterns, and Clovis hunting strategies inferred from isotopic analyses of multiple death assemblages. Paleobiology, 2004, vol.30(1), pp. 129145.

Hoppe K. A., Koch P.L., Carlson R. W., Webb S. D. Tracking mammoths and mastodons: Reconstruction of migratory behavior using strontium isotope ratios. Geology, 2012, vol.27, no. 5, pp.439-442.

Jachmann H. Direct Counts of Elephants From the Ground (Chapter 6). Ed. by K. Kangwana. Studying Elephants. Nairobi, Kenya AWF Technical Handbook Series, 1996, pp. 49-56.

Hoffecker J. F., Kuz'mina I.E., Syromyatnikova E. V., Anikovich M.V., Sinitsyn A.A.Popov V.V., Holliday V.T. Evidence for kill-butchery events of early Upper Paleolithic age at Kostenki, Russia. Journal of Archaeological Science, 2010, vol. 37, pp. 1073-1089.

Holen S. R. Taphonomy of two last glacial maximum mammoth sites in the central Great Plains of North America: A preliminary report on La Sena and Lovewell. Quaternary International, 2006, pp. 30-43.

Honoré P. Das Buch der Altsteinzeit - oder der Streit um die Vorfahren. Düsseldorf, Wien, Econ-Verlag, 1967, 468 s.

Iakovleva L., Djindjian F. New data on Mammoth bone settlements of Eastern Europe in the light of the new excavations of the Gontsy site (Ukraine). Quaternary International, vol. 126-128, 2005, pp. 195-207.

Iakovleva L., Djindjian F., Maschenko E. N., Kronik S., Moigne A.-M. The late Upper Palaeolithic site of Gontsy (Ukraine): A reference for the reconstruction of the hunter-gatherer system based on a mammoth economy. Quaternary International, 2012, vol. 255, pp. 86-93.

Jacob-Friesen K. H. Grosswildjäger des Eiszeitalters in Niedersachsen. Kosmos, Heft 11, November 1949, pp. 408-412.

Kelly M. A., Long A. J. The dimensions of the Greenland Ice Sheet since the Last Glacial Maximum. PAGES News, 2009, vol. 17, no. 2, pp.60-61.

Klassen L. Jade und Kupfer. Untersuchungen zum Neolithisierungsprozess im westlichen Ostseeraum unter besonderer Berücksichtigung der Kulturentwicklung Europas 5500-3500 BC., Aarhus, Jutland Archaeological Society, Moesgard Museum, 2009.

Klein R.G. Age (Mortality) Profiles as a Means of Distinguishing Hunted Species from Scavenged Ones in Stone Age Archeological Sites. Paleobiology, 1982, vol. 8, no. 2 (Spring, 19132), pp. 151-158. 
Koijmans L. Mesolithic Bone and Antler Implements from the North Sea and from the Netherlands. Berichten van de Rijksdienst voor het Oudheidkundig Bodemonderzoek, 1971, Jaargang 20-21, pp. 27-73.

Kozhevnikov J. P., Ukraintseva V.V. Pleistocene tundra-steppe: arguments pro and con. Mammoths and the Mammoth Fauna: Studies of an Extinct Ecosystem. Proceedings of the First International Mammoth Conference St. Petersburg, Russia, October 16-21, 1995. DEINSEA. Eds G. Haynes, J. Klimowicz, J. W. F. Reumer. 1999, vol. 6, pp. 199-210.

Kozlowski J. Mammoth bone accumulations and dwelling structures: discussing some arguments around Krakow-Spadzista B site. Perceived Landscapes and Built Environments. The Cultural Geography of Late Paleolithic Eurasia, BAR International Series. Eds S. A. Vasil’ev, O. Soffer, J. Kozlowski. 2003, vol. 1122, pp.59-64.

Lambeck K., Purcell A., Zhao J., Svensson N.-O. The Scandinavian Ice Sheet: from MIS 4 to the end of the Last Glacial Maximum. BOREAS, 2010 vol. 39, no. 2, 2010, pp. 410-435.

Lawler A. Pre-Clovis Mastodon Hunters Make a Point. Science, 2011, vol.334, 21 October, p. 302.

Layton R. Political and Territorial Structures Among Hunter-Gatherers. Man, New Series, 1986, vol.21(1), mar, pp. 18-33.

Leventer A. Particulate Flux from Sea Ice in Polar Waters. (Eds.) D. N. Thomas \& G. S. Dieckmann, Sea Ice. An Introduction to its Physics, Chemistry, Biology and Geology. Oxford, Blackwell Publishing, 2003, pp. 303-332.

Long A. J., Roberts D.H., Wright M.R. Isolation basin stratigraphy and Holocene relative sea-level change on Arvepinsen Ejland, Disko Bugt, West Greenland. Journal of Quaternary Science, 1999, vol. 14(4), pp.323-345.

Lemke P., Ren J., Alley R. B., Allison I., Carrasco J., Flato G., Fujii Y., Kaser G., Mote P., Thomas R.H., Zhang T. Observations: Changes in Snow, Ice and Frozen Ground. Climate Change 2007: The Physical Science Basis. Contribution of Working Group I to the Fourth Assessment Report of the Intergovernmental Panel on Climate Change. Eds S. Solomon, D. Qin, M. Manning, Z. Chen, M. Marquis, K. B. Averyt, M. Tignor, H. L. Miller. New York; Cambridge, Cambridge University Press, 2007, pp.337-383.

Mackintosh A., Colledge N., Domack E., Dunbar R., Leventer A., White D., Pollard D., DeConto R., Fink D., Zwartz D., Gore D., Lavoie C. Retreat of the Antarctic ice sheet during the last glacial termination. Nature Geoscience, 2011, vol. 4, March, pp. 195-202.

Mangerud J. Ice sheet limits in Norway and on the Norwegian continental shelf. Quaternary Glaciations Extent and Chronology. Eds J. Ehlers, J., P. Gibbard. Vol. 1. Amsterdam, Elsevier, 2004, pp. 271-294.

Mania D., Thomae M., Litt T., Weber T. Neumark-Grobern. Beitrage zur Jagd des mittelpalaolithischen Menschen. Berlin, Deutscher Verlag der Wissenschaften, 1990.

Marquer L., Otto T., Nespoulet R., Chiotti L. A new approach to study the fuel used in hearths by huntergatherers at the Upper Palaeolithic site of Abri Pataud (Dordogne, France). Journal of Archaeological Science, 2010, vol.37, pp. 2735-2746.

Maschenko E. N., Gablina S.S., Tesakov A.S., Simakova A.N. The Sevsk woolly mammoth (Mammuthus primigenius) site in Russia: Taphonomic, biological and behavioral interpretations. Quaternary International, 2006, vol. 142-143, pp. 147-165.

Mol D., Post K., Reumer J. W. F., van der Pflicht J., de Vos J., van Geel B., van Reenen G., Pals J. P., Glimmerveen J. The Eurogeul - first report of the palaeontologica, palynological and archaeological investigations of this part of the North Sea. Quaternary International, 2006, vol. 142-143, pp. 178-185.

Mol D., de Vos J., Bakker R., van Geel B., Glimmerveen J., van der Plicht H., Post K. Mammoeten, neushoorns en andere dieren van de Noordzeebodem. Diemen, Veen Magazines, 2008, 233 p.

Morison J., Kwok R., Peralta-Ferritz C., Alkire M., Rigor I., Steele M. Changing Arctic Ocean freshwater pathways. Nature, 2012, vol. 481, 5 January, pp. 66-70.

Movius Jr. H. L. A Wooden Spear of Third Interglacial Age from Lower Saxony. Southwestern Journal of Anthropology, 1950, vol. 6, no. 2, pp. 139-142.

Münzel, S.C., 2001a. Seasonal hunting of mammoth in the Ach-valley of the Swa-bian Jura. The World of Elephants. Proceedings of the 1st International Congress. Eds G. Cavarretta, P. Gioia, M. Mussi, M. R. Palombo. Rom, Consiglio Nazionale delle Ricerche, 2001, pp.318-322.

Nghiem S. V., Clemente-Colón P., Rigor I. G., Hall D. K., Neumann G. Seafloor control on sea ice. Deep-Sea Research II, 2012, vol.77-80, pp. 52-61.

Nikolskiy P. A., Basilian A.E., Sulerzhitskia LD., Pitulko V. V. Prelude to the extinction: Revision of the Achchagyi-Allaikha and Berelyokh mass accumulations of mammoth. Quaternary International, 2010, vol. 219, pp. 16-25. 
Nikolskiy P. A., Pitulko V. V. Evidence from the Yana Palaeolithic site, Arctic Siberia, yields clues to the riddle of mammoth hunting. Journal of Archaeological Science, 2013, vol.40, pp.4189-4197. https://doi. org/10.1016/j.jas.2013.05.020.

Oakley K. P., Andrews P., Keeley L. H., Clark J. D. A Reappraisal of the Clacton Spearpoint. Proceedings of the Prehistoric Society, 1977, vol.43, pp. 13-30.

Obada T., van der Plicht J., Markova A., Prepelitsa A. Preliminary results of studies of the Valea Morilor Upper Palaeolithic site (Chişinău, Republic of Moldova): A new camp of mammoth hunters. Quaternary International, 2012, vol. 276-277, pp. 227-241.

Odum E. P., Barrett G. W. Fundamentals of Ecology. Belmont, Thomson Brooks/Cole, 2005, 598 p.

Ohnuki-Tierney E. The Ainu of the Northwest Coast of Southern Sakhalin. New York, Holt, Rinehart and Winston, 1974, $127 \mathrm{p}$.

Parry W.E. Journal of a Second Voyage for the Discovery of a North-West Passage from the Atlantic to the Pacific; Performed in the Years 1821-22-23 in his Majesty's ships Fury and Hecla, under the Orders of Captain William Edward Parry, R. N., F. R. S., and Commander of the Expedition. London, John Murray, $1824,571 \mathrm{p}$.

Parducci L., Jørgensen T., Tollefsrud M. M., Elverland E., Alm T., Fontana S. L., Bennett K. D., Haile J., Matetovici I., Suyama Y., Edwards M.E. Andersen K., Rasmussen M., Boessenkool S., Coissac E., Brochmann C., Taberlet P., Houmark-Nielsen M., Krog Larsen N., Orlando L., Gilbert T. P., Kjær K. H., Greve Alsos I., Willerslev E. Glacial Survival of Boreal Trees in Northern Scandinavia. Science, 2012, vol. 335, 2 March, pp. 1083-1087.

Parfitt S.A., Barendregt R.W., Breds M., Collins M.J., Coope G. R., Durbridge P., Field M.H., Lee J.R., Lister A. M., Mutch R., Penkman K.E.H., Preece R. C., Rose J., Stringer C. B., Symmons R., Whittaker J.E., Wymer J. J., Stuart A. J. The earliest record of human activity in northern Europe. Nature, 2005, vol. 438, 15 December, pp. 1008-1012.

Parfitt S. A., Ashton N. M., Lewis S. G., Abel R. L., Russell Coope G., Field M.H., Gale R., Hoare P. G., Larkin N. R., Lewis M. D., Karloukovski V., Maher B. A., Peglar S. M., Preece R. C., Whittaker J.E., Stringer C. B. Early Pleistocene human occupation at the edge of the boreal zone in northwest Europe. $\mathrm{Na}$ ture 2010, vol. 466, 8 July, pp. 229-233.

Peeters H., Murphy P., Flemming N. North Sea Prehistory Research and Management Framework (NSPRMF) 2009. Amersfoort, Rijksdienst voor het Cultureel Erfgoed Ministerie van Onderwijs, Cultuur en Wetenschap, 2009.

Pettipas L. Aboriginal Migrations. A History of Movements in Southern Manitoba. Manitoba, Manitoba Museum of Man and Nature, 1996, 223 p.

Pidoplichko L. G. Upper Palaeolithic Dwellings of Mammoth Bones in the Ukraine. BAR International Series 712. Oxford, British Archaeological Reports Oxford Ltd, 1998, 328 p.

Pitulko V.V. The Berelekh Quest: A Review of Forty Years of Research in the Mammoth Graveyard in Northeast Siberia. Geoarchaeology, 2010, vol. 26, no. 1, pp. 5-32.

Pitulko V.V., Nikolskiy P. A., Basilyan A. E., Pavlova E. Y. Dating mass accumulations of mammoth across Arctic Eurasia. The Quaternary in all of its variety. Basic issues, results, and major trends of further research. Proceedings of the VII All-Russian Quaternary Conference (Apatity, September 12-17, 2011). Eds P. Korsakova, V. V. Kolka, L. D. Chistyakova. 2011, vol. 2, pp. 146-149.

Pitulko V.V., Yakshina I., Strauss J., Schirrmeister L., Knzuetsova T., Nikolskiy P., Pavlova E. Y. A MIS 3 kill-butchery mammoth site on Buor-Khaya Peninsula, Eastern Laptev Sea, Russian Arctic. Scientific Annals, School of Geology, Aristotle University of Thessaloniki, Greece, VIth International Conference on Mammoths and their Relatives, Grevena - Siatista. Thessaloniki, 2014, special volume 102, pp. 158-159.

Pitulko V.V., Pavlova E. Y., Basilyan A.E. A MIS 3 kill-butchery mammoth site on Buor-Khaya Peninsula, Eastern Laptev Sea, Russian Arctic. Scientific Annals, School of Geology, Aristotle University of Thessaloniki, Greece, VIth International Conference on Mammoths and their Relatives, Grevena - Siatista, Thessaloniki, 2014, special volume 102, p. 155.

Pitulko V.V., Basilyan A.E., Pavlova E. Y. 2 The Berelekh Mammoth "Graveyard”: New Chronological and Stratigraphical Data from the 2009 Field Season. Geoarchaeology, 2014, vol. 29, pp. 277-299.

Praslov N. Outils de chasse du Paleolithique de Kostenki. Anthropologie et Prehistoire 2000, vol. 111, p. 37.

Praslov N. D., Stanko V.N., Abramova Z. A., Sapozhnikov I. V., Brozijak I. A. The steppes in the Late Palaeolithic. Antiquity, 1989, vol. 63 (241), pp. 784-792.

Putnam A. E. Eight Years with Congo Pigmies. London, Hutchinson, 1955. 192 p. 
Putshkov P.V. The impact of mammoths on their biome: clash of two paradigms. Advances in Mammoth Research. Proceedings of the Second International Mammoth Conference, Rotterdam, May 16-20, 1999. DEINSEA 9. Eds J. W. F. Reumer, J. de Vos, D. Mol. 2003, pp. 365-379.

Påsse T., Andersson L. Shore-level displacement in Fennoscandia calculated from empirical data. GFF, 2005, vol. 127, pp. 253-268.

Raghavan M. et al. Upper Palaeolithic Siberian genome reveals dual ancestry of Native Americans. Nature, 2014, vol. 505, 2 January, pp. 87-94.

Ramos J., Domíguez-Bella S., Cantillo J. J., Soriguer M., Pérez M., Hernando J., Vijande E., Zabala C., Clemente I., Bernal D. Marine resources exploitation by Palaeolithic hunter-fisher-gatherers and Neolithic tribal societies in the historical region of the Strait of Gibraltar. Quaternary International, 2011, vol. 239, pp. 104-113.

Ray A. J. Some Thoughts about the Reasons for Spatial Dynamism in the Early Fur Trade. 1580-1800. Three Hundred Prairie Years: Henry Kelsey's "Inland Country of Good Report". Ed. by Henry Epp. Regina, Canadian Plains Research Center, University of Regina, 1993, pp. 113-123.

Reich D., Patterson N., Campbell D., Tandon A., Mazieres S. et al. Reconstructing Native American population history. Nature, 2012, vol.488, 16 august, pp.370-376.

Reid C. Submerged Forest. Cambridge, Cambridge University Press, 1913, 138 p.

Reimer R. Reassessing the role of Mount Edziza obsidian in northwestern North America. Journal of Archaeological Science: Reports, 2015, vol.2, pp. 418-426.

Richards M. P., Jacobi R., Cook J., Pettitt P. B., Stringer C. B. Isotope evidence for the intensive use of marine foods by Late Upper Palaeolithic humans. Journal of Human Evolution, 2005, vol. 49, pp. 390-394.

Schebesta P. Die Negritos Asiens. Band II: Etnographie der Negrito. Halbband 1: Wirtschaft und Soziologie. St.Gabriel Verlag, Mödling bei Wien, 1954, 336 p.

Sejrup H. P., Larsen E., Landviken J., King E. L., Haflidason H., Nesje A. Quaternary gaciations in southern Fennoscandia: evidence from southwestern Norway and the northern North Sea region. Quaternary Science Review, 2000, vol. 19, pp. 667-685.

Sejrup H.P., Larsen E., Haflidason H., Berstad I. M., Hjelstuen B. O., Jonsdottir H., King E. L., Landvik J., Longva O., Nygård A., Ottesen D., Raunholm S., Rise L., Stalsberg K. Configuration, history and impact of the Norwegian Channel Ice Stream. Boreas, 2003, vol.32, pp. 18-36.

Shackleton J. C., van Andel T. Prehistoric Shore Environments, Shellfish Availability, and Shellfish Gathering at Frantchi, Greece. Geoarchaeology, 1986, vol. 1, no. 2, pp. 127-143.

Sharp Z.D., Atudorei V., Panarello H.O., Fernández J., Douthitt C. Hydrogen isotope systematics of hair: archeological and forensic applications. Journal of Archaeological Science, 2003, vol. 30, pp. 1709-1716.

Shternberg L.I. The Social Organisation of the Gilyak. Bruce Grant, Swarthmore College, Anthropological Papers of The American Museum of Natural History, 1999, no. 82, 336 p.

Sinitsyn A. A., Praslov N. D., Svezhentsev Yu. S., Sulerzhitskii L. D. Radiouglerodnaia khronologiia paleolita Vostochnoi Evropy. Radiouglerodnaia khronologiia paleolita Vostochnoi Evropy i Severnoi Azii. Problemyi i perspektivy. Eds A. A. Sinitsyn, N. D. Praslov. St. Petersburg, IIMK RAN, 1997, pp.21-66. (In Russian)

Skaarup J., Grøn O. Møllegabet II. A submerged Mesolithic settlement in southern Denmark. BAR International Series 1328. Oxford, Archaeopress, 2004, 199 p.

Smit I. P. L., Grant C. C., Whyte I. J. Landscape-scale sexual segregation in the dry season distribution and resource utilization of elephants in Kruger National Park, South Africa. Biodiversity Research, 2007, vol. 13, pp. 225-236.

Soffer O. The Upper Paleolithic of the Central Russian Plain. New York, Academic Press, 1985, 539 p.

Sulgosłowska Z. Mesolithic mobility and contacts on areas of the Baltic Sea watershed, the Sudety, and Carpathian Mountains. Journal of Anthropological Archaeology, 2006, vol. 25, pp. 193-203.

Sutton P. The Pulsating Hearth: Large Scale Cultural and Demographic Processes in Aboriginal Australia. Hunter-Gatherer Demography. Past and Present. Eds B. Meehan, N. White. Sydney, University of Sydney, 1990, pp. 71-80.

Svendsen J.I., Alexanderson H., Astakhov V.I.Demidov I., Dowdeswell J.A., Funder S., Gataullin V., Henriksen M., Hjort C., Houmark-Nielsen M., Hubberten H. W., Ingólfsson Ó., Jakobsson M., Kjær K. H., Larsen E., Lokrantz H., Lunkka J.P., Lyså A., Mangerud J., Matiouchkov A., Murray A., Möller P., Niessen F., Nikolskaya O., Polyak L., Saarnisto M., Siegert C., Siegert M. J., Spielhagen R. F., Stein R. Late Quaternary ice sheet history of northern Eurasia. Quaternary Science Reviews, 2004, vol.23, pp. 1229-1271. 
Svoboda J., Péan S., Wojtal P. Mammoth bone deposits and subsistence practices during Mid-Upper Palaeolithic in Central Europe: three cases from Moravia and Poland. Quaternary International, 2005, vol. 126-128, pp. 209-221.

Svoboda J., Bocheński Z.M., Čulíková V., Dohnalová A., Hladilová S., Hložek M., Horáček I., Ivanov M., Králík M., Novák M., Pryor A. J.E., Sázelová S., Stevens R. E., Wilczyński Wojtal P. Paleolithic Hunting in a Southern Moravian Landscape: The Case of Milovice IV, Czech Republic. Geoarchaeology: An International Journal, 2011, vol.26, no. 6, pp. 838-866.

Swagerty W. R. Indian Trade in the Trans-Mississippi West to 1870. Handbook of North American Indians Vol. 4: History of Indian - White Relations. Eds W. E. Washburn \& W. C. Sturtevant. Washington, Smithsonian Institution, 1988, pp. 351-374.

Thieme H. Lower Palaeolithic hunting spears from Germany. Nature, 1997, vol.385, iss.6619, pp. 807-810.

Thomas B., Holland J. D., Minot E. Seasonal home ranges of elephants (Loxodonta africana) and their movements between Sabi Sand Reserve and Kruger National Park. African Journal of Ecology, 2011, vol. 50, iss. 4 , pp. 131-139.

Trueman C.N. G., Behrensmeyer A. K., Tuross N., Weiner S. Mineralogical and compositional changes in bones exposed on soil surfaces in Amboseli National Park, Kenya: diagenetic mechanisms and the role of sediment pore fluids. Journal of Archaeological Science, 2004, vol.31, pp.721-739.

Turnbull C. M. The Forest People. New York, Simon \& Schuster, 1961, 330 p.

Turnbull C.M. The Mbuti Pygmies: An Ethnographic Survey. Vol.50, part 3. New York, Anthropological Papers of the American Museum of Natural History, 1965, pp. 141-282.

Turnbull C. M. The Mbuti Pygmies. Change and Adaptation. New York, Holt, Rinehart and Winston, 1983, $161 \mathrm{p}$.

Tizzard L., Bicket A., De Loecker D. Seabed Prehistory. Investigating the Palaeogeography and Early Middle Palaeolithic Archaeology in the Southern North Sea. Salisbury, Wessex Archaeology, 2015, 152 p.

Vereshchagin N.K. The mammoth 'cemeteries' of North-East Siberia. Polar Record, 1974, vol.17, no. 106, pp. 3-12.

Vereshchagin N. K. Berelekh mammoth graveyard. Trudy Zoologicheskogo Instituta, 1977, vol.72, pp.5-50. (In Russian)

Vereshchagin N. K., Tomirdiaro S. V. Taphonomic research in permafrost regions: a survey of past and present studies in the former Soviet Union. Mammoths and the Mammoth Fauna: Studies of an Extinct Ecosystem. DEINSEA. Eds G. Haynes, J. Klimowicz, J. W. F. Reumer. 1999, vol. 6, pp. 187-198.

Villa P., Soto E., Santonja M., Pérez-Gonzáles A., Mora R., Parcerisas J., Sesé C. New data from Ambrona: closing the hunting versus scavenging debate. Quaternary International, 2005, vol. 126-128, pp. 223250.

de Warrimont J.P.L.M.N. Prospecting Middle Palaeolithic open-air sites in the Dutch-Belgian border area near Maastricht. PalArch's Journal of Archaeology of Northwest Europe, 2007, vol. 1, iss. 3, pp. 40-89.

Watanabe H. The Ainu Ecosystem. Environment and Group Structure. Seattle, University of Washington Press, 1973, $170 \mathrm{p}$.

Waters M.R., Stafford T.W.jr., McDonald H.G., Gustafson C., Rasmussen M., Cappellini E., Olsen J.V., Szklarczyk D., Jensen L. J., Gilbert T. P., Willerslev E. Pre-Clovis Mastodon Hunting 13,800 Years Ago at the Manis Site, Washington. Science 2011, vol.334, 21 October, pp. 351-353.

Weidick A. Satellite Image Atlas of Glaciers of the World. Greenland. United States Geological Survey. Professional Paper 1386-C. Washington, United States Government Printing Office, 1995, 141 p.

Weidick A., Bennike O. Quaternary glaciation history and glaciology of Jakobshavn Isbroe and the Disko Bugt region, West Greenland: a review. Copenhagen, Geological Survey of Denmark and Greenland Bulletin $14,2007,78 \mathrm{p}$.

Western D., Lindsay W. K. Seasonal herd Dynamics of a Savanna Elephant Population. African Journal of Ecology, 1984, vol.22, iss. 4, pp. 229-44.

Whyte I. J. Studying Elephant Movements. Whyte I. J. Studying Elephants. Ed. by K. F. Kangwana, Nairobi, AWF Technical Handbook Series, 1996, pp. 75-89.

Wikell R., Molin F., Pettersson M. The archipelago of Eastern Middle Sweden - Mesolithic settlement in comparison with $\mathrm{C} 14$ and shoreline dating. Chronology and Evolution within the Mesolithic of NorthWest Europe. Eds P. Crombé, M. van Strydonck, J. Sergant, M. Boudin, M. Bats. 2009, pp.417-34.

Willerslev E., Davison J., Moora M., Zobel M., Coissac E., Edwards M.E., Lorenzen E. D., Vestergard M., Gussarova G., Haile J., Craine J., Gielly L., Boessenkool S., Epp L. S., Pearman P. B., Cheddadi R., Murray D., Brathen K. A., Yoccoz N., Binney H., Cruaud C., Wincker P., Goslar T., Alsos I. G., Bellemain E., Brysting A. K., Elven R., Sonstebo J.H., Murton J., Sher A., Rasmussen M., Ronn R., Mourier T., Cooper A., Austin J., Moller P., Froese D., Zazula G., Pompanon F., Rioux D., Niderkorn V., Tikhonov A., 
Savvinov G., Roberts R.G., MacPhee R.D.E., Gilbert M.T.P., Kjar K., Orlando L., Brochmann C., Taberlet P., 2014. Fifty thousand years of Arctic vegetation and megafaunal diet. Nature, 2014, vol.506, 6 February, pp. 47-51.

Wittemyer G. W., Getz W. M., Vollrath F., Douglas-Hamilton I. Social dominance, seasonal movements, and spatial segregation in African elephants: a contribution to conservation behaviour. Behavioral Ecology and Sociobiology, 2007, vol.61, no. 12 (October), pp. 1919-1931.

Wojtal P., Sobczyk K. Taphonomy of the Gravettian site - Kraków Spadzista Street (B). DEINSEA, 2003, vol. 9, pp. 557-562.

Wojtal P., Wilczyński J., Bocheński Z.M., Svoboda J.A. The scene of spectacular feasts: Animal remains from Pavlov I south-east, the Czech Republic. Quaternary International, 2012, vol. 252, pp. 122-141.

Zenin V.N., Leshchinskiy S. V., Zolotarev K. V., Grootes P. M., Nadeau M.-J. Lugovskoe: geoarchaeology and culture of a Paleolithic site. Archaeology, Ethnology and Anthropology of Eurasia, 2006, vol.25, pp. 41-53.

Zwilling E. A. Unvergessenes Kamerun. Zehn Jahre Wanderungen und Jagden 1928-1938. Berlin, Verlag von Paul Parey, 1941, 384 S.

Статья поступила в редакцию 30 мая 2018 г. Рекомендована в печать 12 марта 2019 г.

Received: May 30, 2018

Accepted: March 12, 2019 